\title{
FETIHTEN 19. YÜZYILIN SONUNA KADAR YOL-KÖPRÜ HIZMMETI VEREN DOĞU KARADENIZ ZAVIYE VE DERBENDLERI İLE GÜNÜMÜZE ULAŞAN TEK AÇIKLIKLI KEMER KÖPRÜLER
}

\author{
20ล \\ ZAWIYAHS, DERBENDS AND SINGLE-SPAN ARCHED BRIDGES WHICH \\ ARE STANDING TODAY AND PROVIDED ROAD \& BRIDGE SERVICE IN \\ THE REGION OF EASTERN BLACK SEA FROM THE CONQUEST TILL \\ END OF $19^{\text {th }}$ CENTURY
}

Seyfi BAŞKAN*

\begin{abstract}
$\underline{\ddot{O}_{\mathbf{z}}}$
Bu makalede, ilk iskân yıllarından başlayarak Osmanlı Devletinin son dönemlerine kadar, Doğu Karadeniz' de kurulmuş zâviye ve derbendler ile bu organizasyonlar tarafindan çeşitli tarihlerde yapılmış, bakım ve onarımından da sorumlu oldukları tek açıklıklı taş kemer köprüler incelenmiştir. Öncelikle, Orta Asya'dan zengin bir kültürel hafıza ile yola çıkan Türk topluluklarının, batıya göç safahatında yolda karşılaştıkları kültürlerden aldıkları ve Anadolu'ya geldiklerinde bu topraklarda buldukları kadim mirasın ortak bir yaratması olan tekke, zâviye ve derbendlerin kuruluş dönemlerinde Anadolu Türk kültürüne olan katkıları değerlendirilmeye çalışılmıştır. Ardından, yüzlerce yıl boyunca, belki de bölgedeki her sel afetinden sonra yenilenmek zorunda kalınan yerel yapıcılık sanatının seçkin ürünleri olan kemer köprüler hakkındaki temel sorunlara cevap aranmıştır. Metinde, Anadolu Ortaçağının ve takip eden dönemlerin kendine özgü koşullarında oluşan zâviye ve derbendler ile kemer köprüler; şekillendikleri ekonomik ve sosyo-kültürel, ortam ile mimari özelliklerinin beraber aktarılması bir yöntem kurgusu olarak ele alınmıştır. Ancak, tekke ve zaviyelerden söz ederken, konuya sosyo-kültürel perspektiften yaklaşılarak, mimarlık ve sanat tarihi projeksiyonuna öncelik verilmiş, Ortaçağ Türk toplumdaki İslâm odaklı toplumsal/ dinsel örgütlenmeler ve özellikle İslamî alt felsefelerin gelişim ilişkisi konu edilmemiştir. Özellikle, Doğu Karadeniz'in 15. yüzyılda fethiyle birlikte bu coğrafyadaki derin vadilerde oluşan yerleşik yaşam kültürü ve bu yaşam deneyimlerinin en önemli anıtsal ürünlerinden olan kemer köprülerin tarihi belge ve bulgulara yansıyan takibi yapılarak günümüze ulaşan örneklerle bağlantıları kurulmaya çalışılmıştır. Diğer bir deyişle, önemli bir kültür varlığg ve maddi miras olan bu yapıların kuşaktan kuşağa aktarılması hakkındaki yaşayan mimarlık hafızası, tarihi arka planda ele alınarak anlatılmaya çalışılmıştır.
\end{abstract}

Anahtar Kelimeler: Doğu Karadeniz, Zâviye, Tekke, Derbend, Kemer Köprü,

* Dr. Öğretim Üyesi, Ankara Hacı Bayram Veli Üniversitesi, Edebiyat Fakültesi, Sanat Tarihi Bölümü, Ankara. ORCID ID: 0000-0001-5514-7585 • E-mail: seyfi.baskan@hbv.edu.tr

Makale, Giresun, Trabzon, Rize, Gümüşhane ve Artvin illerinde 2002-2017 yılları arasında sürdürülen çalışmalar kapsamında, 2009-2011 yılları arasında Gazi Üniversitesi'nce desteklenen, "Tek Açıklıklı Doğu Karadeniz Kemer Köprüleri / Single Span Eastern Black Sea Humpback Bridges. Gazi Üniversitesi Rektörlüğü Bilimsel Araştırma Projeleri. 05/2009-42.Ankara" başlıklı, Bilimsel Araştırma Projesi sonuçlarıyla hazırlanmıştır. 


\begin{abstract}
In this article, the zawiyahs and derbends as organizations that served the road and bridge construction services in the Eastern Black Sea from the $12^{\text {th }}$ century as the first Turkish-Islamic colonization period of Anatolia until the last century of the Ottoman Empire, and the examples of this architectural tradition formed within the functional regional stages of these organizations in the region have been addressed. The contributions made to the Turkish culture in Anatolia by the Turkic tribes and clans migrated from the Central Asia to the west with a rich collection of cultural and traditional assets, and the ones made by the lodges, zawiyahs and derbends as a reflection of an ancient heritage when they were founded were discussed in the study. Within this context, the basic questions about these outstanding works of the regional and local art of construction, which had to be rebuilt after every disastrous flood in the region throughout the centuries were answered. In other words, revealing the architectural features of arch bridges together through spatial and functional organizations formed in the unique mystical environment of the changing and transforming conditions of the changing military-political conditions of the Middle Ages and the socio-cultural and economic relations of the Middle Ages was considered as a methodology. When talking about lodges and zawiyahs, the issue was addressed from a socio-cultural perspective, prioritizing the projection of architecture and the history of art but the relationship between Islamic-oriented religious organizations and especially the development of Islamic sub-philosophies in medieval Turkish societies were not discussed. The bridges are one of the most important products of the settled life culture and the experiences in the deep valleys of this geography with the conquest of the Eastern Black Sea in the 15th century. In particular, these structures and the architectural memory about them, which have been discussed within the scope of history in this study, were inherited from generation to generation as material and spiritual heritage.
\end{abstract}

Keywords: Eastern Black Sea, Zawiyahs, Lodges, Derbend, Arched Bridge,

\title{
I. Giris
}

Jeopolitik konumu nedeniyle tarihin her döneminde üç eski kıta arasında bir geçit olan Anadolu' da, çok eski çağlardan beri bu coğrafyada yaşayan kültürler tarafından ticari ve askeri amaçlı yollar yapılmıştır. Türklerin Anadolu'ya geldikleri 11. yüzyıldan sonra da bu tarihi yolların bakım ve onarımının sürekliliği sağlanarak, karşılıklı ticaret için güvenli ortamlar oluşturulmuş, Asya-Avrupa arasındaki ticaretin sürdürülebilirliği sağlanmıştır. Çin içlerinden çıkarak Anadolu üzerinden Avrupa'ya ulaşan, 'Ípek Yolu' denilen ve bir bakıma zamanının dünya ticaretinin gerçekleştiği bu ticaret yolu, geçtiği yerlere zenginlik vermiştir.

Ortaçağ'da, Anadolu'daki Selçuklu ticaret yolları, çok iyi organize olmuş hanlar/ kervansaraylar düzeni ile varlığı ve sürdürülebilirliği sağlanmıştır. Anadolu'da yapılan, 
savunma ve güvenlik işlevleri yanı sıra sosyal ve ticaret amaçlı han, kervansaray, ribat, zâviye, hângâh/hânikah gibi yapılar sistemi planlama ve işleyiş bakımından Orta AsyaOrta Doğu kaynaklı olmakla birlikte, Roma çağı 'castrum' ları ve Bizans 'kreneidon'

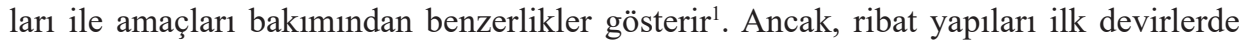
sınır boylarında, "cihad ve gazâ için gönüllü savaşan gazilerin yaşadıkları müstahkem mevkilere denmekte iken zamanla bunlar tasavvufi bir niteliğe bürünüp zâviye haline gelmişlerdir". ${ }^{2}$ Yani, başlangıçta sınır boylarında müstahkem mevki olarak inşa edilen ribat yapıları, zamanla İslâmiyetin Orta Asya'da yayılmaya başladığı 8. yüzyıldan itibaren savunma ve güvenlik işlevlerini yitirerek tekke, türbe ve zâviye ${ }^{3}$ gibi yapıların ilavesiyle yeniden şekillenmiş ve anlam kazanmıştır.

8. yüzyılın sonlarıyla 9. yüzyılın başlarından itibaren İslâm dünyasında gelişmeye başlayan tasavvuf akımıyla birlikte, o zamana kadar yalnızca Budizm, Yahûdîlik ve Hıristiyanlık gibi mistik bir düşünüş ve yaşayış biçimi sunan dinlerin yayıldığı alanlarda görülen zâviyelerin İslâm dünyasında doğuşu da bu tasavvuf akımının başlangıcı ile görülür. ${ }^{4}$ Tahrir kayıtlarında, "ehl-i velâyet ve sahib-i kerâmet" ya da "sâlih ve mütedeyyin ve riâyeti vâcib kimesne"ler oldukları özellikle vurgulanan, zaviyenin kurucusu da olan şeyh" adı ile anılan otoritenin yönetiminde, ortak tasavvuf düşüncesini paylaşan kimselerin bir arada yaşadıkları bu müesseselerin ilk örnekleri hakkında fazla bilgi yoktur. Ancak, başlangıçta güvenlik amaçlı kurulan yapılara zamanla burada yaşayanların ihtiyaçlarını karşılayacak cami, medrese vb. yapıların eklenmesi ve tesisin kurucusunun ölümünün ardından da mezarının sonraki kuşaklar tarafından türbe yapılarak ruhaniyet atfetmesiyle oluşan bu mekânsal ve ruhani organizasyon aidiyeti Orta Asya geleneklerine dayanır. Harezm'deki Oğuz illerinde ve Türkistan'da Göktürk Çağı'ndan başlayarak yapılmış olan bazı korunaklı kervan menzil yapıları İslâmiyetin bu bölgelerde yayılmasından sonra hankâh olarak kullanılmışlardır. ${ }^{6}$

1 Yavuz,1992, 253.

2 Ocak, 1978, 241.

3 "Arşiv belgelerinde, dayanak, dayanılan yer veya tarikat mensuplarının bir arada yaşadıkları yer anlamina gelen dini, sosyal işlevleri olan yer ve mekânlar için, zaviye, hankâh, dergâh, asitane ve tekke sözcükleri kullanılır. Zaviye'nin, tekkelerin küçüklerine, âsitâne veya hânkâh/ hanekâh'ın da, büyük hacimli tekkeler için kullanıldı̆̆ l da olur. Yanısıra, dağlar arasındaki geçitlerde ve derbendlerdeki konaklama yapılan mekanlar da zaviye olarak adlandırllır." (Pakalın, 1993, III/648). Anadolu'da ilk örnekleri hakkında bir başlangıç belirlemek zor olsa da 12. Yüzyıldan itibaren Selçuklu, Beylikler ve Osmanlı'nın son dönemlerine kadar vakıf niteliğini taşıyan büyük çiftliklere, bağ, bahçe ve arazilere sahip bu tekke veya zaviyelerde sadece tarikat mensuplarına değil, menzilden geçen yolculara da güvenli konaklama ve ulaşım imkânı sağlanırdı. (Bk. Gülçiçek, 2000;Ocak, 1978; Görkaş,2000,191-211;Özdemir, 1994.)

4 Ocak, 1978, 241.

5 Bostan, 2013, 48.

6 Esin 1972, 79,83,85. "Emel Esin, Türk mimarisinde; mescid, yolcu barınă̆l, karakol vb. ünitelerin bir arada planlanarak yapıldı $\breve{l}$ veya zamanla farklı ihtiyaçlara cevap veren ünitelerin de eklendiği İslâm dönemindeki Orta Asya ribatlarının ilk örneklerinin İ.Ö. 3. yüzylldan 


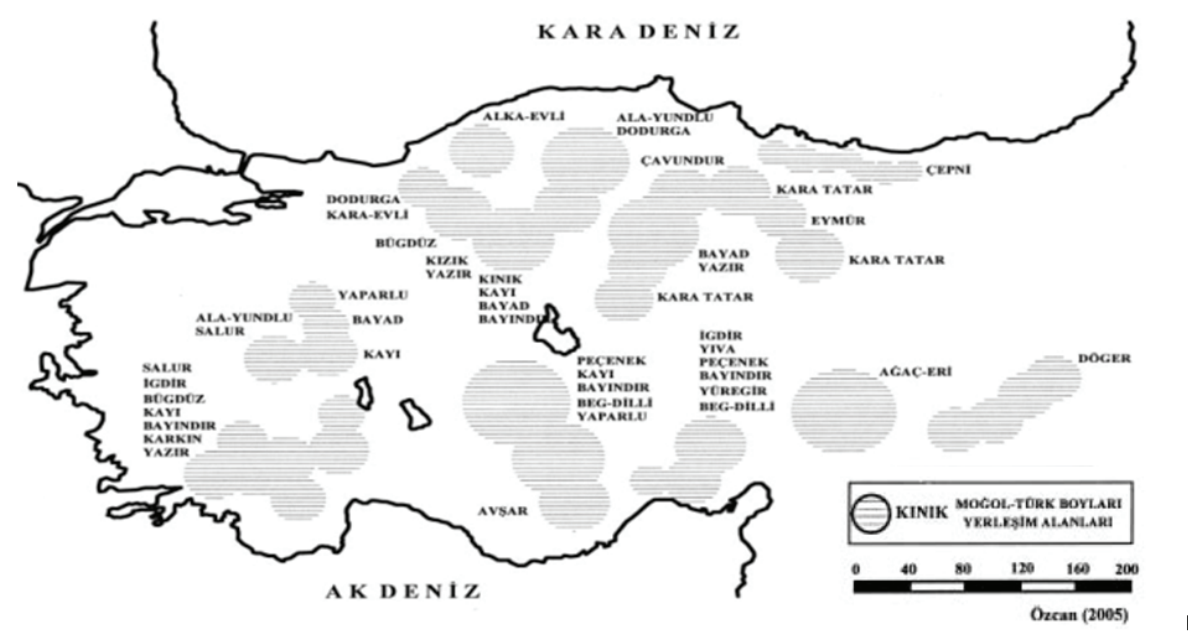

Harita 1: 11-13. yüzyıllarda Anadolu Türkmen göçleri ve yerleşim alanları. (Özcan, 2005, 43)

Tekke ve zâviyeler ile buralarda yaşayan, kendilerine 'Abdal', 'Baba' veya 'Horasan Erenleri' de denilen bu kolonizatör dervişler, Türkmen aşiretleri üzerindeki tesirleriyle Anadolu'nun Türk kitlelerine açılması ve Türklerin yerleşik hayata geçmelerinde etkin olmuşlardır. ${ }^{7}$ Ö. L. Barkan'ın ifadesiyle bu kolonizatör dervişler "çorak toprakları işlemek için yerleşen, evlâdları çoğalınca köyler tesis eden ve yerleştikleri topraklarl yavaş yavaş bir kültür ve iktisat merkezi bir ma 'mure haline sokan.. Bir asker gibi harb edebildiği halde bir köylü gibi çalışan.. rüsumdan muaf olmakla birlikte öşürlerini devlete ödeyen" Anadolu'yu Türkleştiren öncüler, "zâhid ve tufeylî bir zümre teşkil etmekten ziyade; Çalışmak ve topră̆l açmak muhabbetile müteharrik bir sınıf kolon, kırlara doğru taşmakta ve yayılmakta olan bir cemiyetin doğurduğu canlı ve müteşebbis bir tip insan(lar)dır". ${ }^{8}$

itibaren Burkan dînine (Budizm) bağlı Türk çevrelerinde "buyan" adı ile Burkan rahiplerinin (Türkçesi Toyun) eğitim, barınak ve ibadet ihtiyaçları için yapıldı̆̆ını yazar. İslâmiyet öncesi Burkan dînine (Budizm) mensup Türklerce yapılan bu Burkan (Budist) hayrat külliyelerinin mimari plan şemasl ve yapı formlarının takip eden dönemlerde de bir gelenek olarak devam ettirildiğini ve İslâmiyetle birlikte Türk İslâm mimarisine kazandırıldiğını belirtir. 630 yılında Batı Türkistan'a gelen Çin'li Budist keşiş Hsüan-tsang (602-664)'in seyahatnâmesinde Semerkant’ta gördü̈̆̈̈nü söylediği iki Burkan hayrat külliyesi hakkındaki izlenimlerini de örnek olarak gösterir. İslâmiyetin Orta Asya'da yayılmaya başladığı 8. yüzylldan itibaren Harezm ve Maveraünnehir'e gelen Müslüman Arap gezginlerin ribât veya hankâh olarak adlandırdıklar bu külliyelerin İslâmiyetle birlikte şeklen devam ettikleri anlaşılmaktadır.” Başkan, 2012, 145.

7 Barkan, 1942, 279-386.

8 Barkan, 1942, 293-299. 
$\mathrm{Bu}$ Anadolu alperenleri, fetih sürecinde katıldıkları savaşlardan sonra kendilerine tımar olarak verilen topraklara yerleşerek buralarda kurdukları zaviyelerle Anadolu'nun iskânında etkin olmuşlardır. Özellikle Anadolu'nun erken fetih yıllarında, Mengücekli, Danimedli ve Saltuklu dönemlerinden başlayarak 15-16. yüzyıllara kadar Anadolu'nun pek çok yerinde, Türkmen beyleri fetihler sırasında gazilik ananelerine özel önem vererek kendileriyle beraber gaza yapan bu tasavvuf ehli alperenlerden; âlimlere, medrese, şeyhlere zaviye ve imaretler inşa etmişlerdir. Bu müesseseler, dönemlerinin sosyal yapısını düzenleyici rolleri yanı sıra 12-14. yüzyıllar boyunca Anadolu'da gezici atölyeler şeklinde örgütlenmiş olan zamanlarının zenaat-sanat erbabının faaliyetlerinde de etkin rol oynamışlardır.

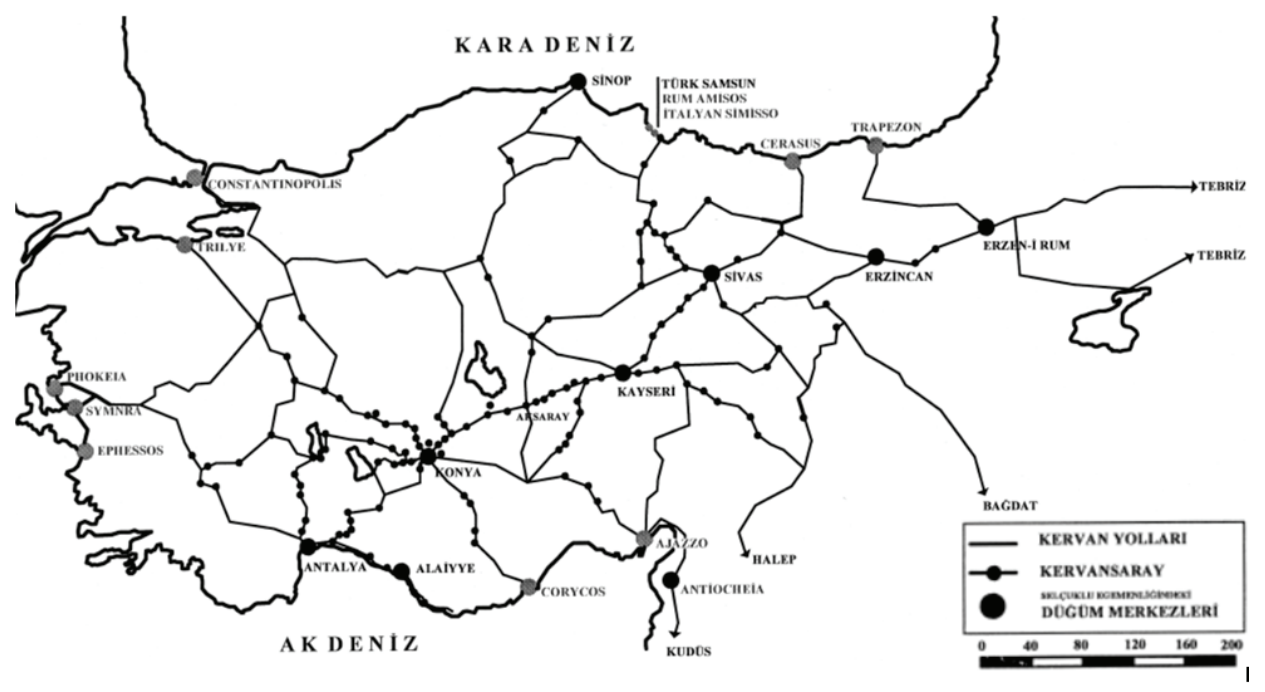

Harita 2: Ortaçă̆'da Anadolu Yolları ve Kervansarayları. (Özcan, 2005, 40)

\section{Doğu Karadenizde Türk Yerleşmeleri}

15. yüzyılda bölgenin fethi ile beraber ticaret güzergâhlarında ortaya çıkan güvenlik sorunu, başlangıçta, doğu-batı yönünde sahil boyunca güneye yol veren vadi ağızlarında veya vadi içlerinde, muhtemelen büyük bir kısmı daha eski dönemlerde yapılmış küçük kalelerin kullanılması ile çözülmeye çalışılmıştır. Ancak sorun, bölgeye yerleştirilen göçebe Türkmenlerin hem güvenlik ihtiyacını karşılamak, hem de bu göçebe unsurları toprağa bağlamak üzere, zâviyeler ve derbendlerin tesis edilmesiyle çözülmüştür.

Osmanlı arşiv belgelerinde 15-16. yüzyıllardan sonra izlenebilen, bu zâviye ve derbendler, kapalı bir havza olan Karadeniz'in sahil kesimini Anadolu'nun diğer 
bölgelerine bağlayan tarihi geçitler ve yollar üzerinde yer almıştır. Geç dönemlere kadar, Yeşilırmak ve Çoruh Nehri arasındaki Doğu Karadeniz vadilerini birbirine bağlayan devamlı bir karayolu bulunmadığından, bölgedeki yolların, köprülerin bakım onarım ve güvenliğini sağlayan zâviye ve derbendler, nadiren doğu-batı yönündeki Karadeniz vadilerinde görülürken, daha çok güneye, Anadolu içlerine açılan vadi ağızları ve içlerinde kurulmuşlardır.

Sultan II. Mehmet'in, Trabzon Rum İmparatorluğu, Karamanoğulları ve Akkoyunluları yenerek Anadolu jeopolitiğine egemen olmasıyla Anadolu'nun istikrar kazanmasının ardından Orta ve Doğu Karadeniz'in batı uçlarından başlayarak Erzincan'a kadar bir alanda iskân faaliyetinin yoğunlaştığı görülür. Bu durum, Giresun'un doğu kısmında yer alan Aksu vâdisinden başlayarak Erzincan, Bayburt, Gümüşhane ve Rize yöresini kapsayan Trabzon Beylerbeyliği ile Çorum, Canik, Amasya, Tokat, Sivas ve Karahisar-1 sarkî sancaklarını Vilayet-i R̂̂m-ı Kadim imlasıyla içine alan iki eyalet içindeki iskân faaliyetlerinin bir kuşak sonra Osmanlı vergi defterlerine yansımasından anlaşılmaktadır. ${ }^{9}$ Özellikle arşiv belgelerine yansıyan bu dönemdeki kolonizasyon etkinliği, “Bayburt, Gümüşhâne, Şebinkarahisar ile Giresun'un doğusunda kalan Görele, Tirebolu, Doğankent, Güce, Espiye, Kesap ve Eynesil'i de kapsayan ve vergi defterlerinde "Kürtün Kazası" şeklinde geçen, daha çok gayrimüslim nüfusun az olduğu veya hiç bulunmadı̆̆ı açık alanlarda yoğunlaşmıştır". ${ }^{10}$

15 yüzyılın sonlarına gelindiğinde, Anadolu'nun kuzey doğusu da önemli nüfus hareketlerine sahne olur. Miladın ilk yüzyıllarına kadar geri giden bölgeye Oğuz göçleri, özellikle 11. yüzyıldan başlayıp 14. Yüzyıla kadar artarak devam etmiş ve "Doğu Karadeniz 16. Yüzyılın ortalarında artık bir Ŏguz coğrafyası hâline gelmiştir". ${ }^{11}$

Özellikle daha, "XI. yüzyılda Canik, Karahisar-i Şarki ve Trabzon sancaklarında Ŏguz boyları iskân hâlindedir. Bunlar; Karkınlu, Karkın, Bayındır, Çavuldur (Çavundur), Çepni, Çepnilü, Çepni (Ăgaç), Çepni-Günü, Salur, Eymür (Eymir), Ala- Yundlu, Yüregir (Üregir), İgdir, Aşağı-Kınık, Kızık, Avşar, Yazır ve Kayı boylarıdır. Samsun'un Vezirköprü̈, Kavak, Alaçam, Lâdik, Havza, Bafra ilçeleri de Ŏ̆uz boylarının yoğun yaşadığı yerlerdir ${ }^{12 ”}$. Örneğin, “Çepniler'den yüz bin kişilik bir kitle Doğu Karadeniz bölgesine gelerek Tirebolu, Görele ve Vakfikebir yörelerine yerleşmişlerdir". ${ }^{13}$ Anadolu'ya gelişleri hakkında kesin bir bilgi bulunmamakla birlikte bazı kaynaklarda, Çepnilerin bölgeye yerleşmeleri hakkında, "Çepniler iki koldan Karadeniz sahillerine inmişlerdir. Bunlardan ilki Harşid deresi ve civarına yerleşenler, ikincisi de 1277'de Sinop baskınını bertaraf ederek batıya ve Samsun 'dan sahil şeridini takip ederek doğuya doğru ilerleyen gruplardır"

9 Bostanc1, 2007.

10 Bostanc1, . 2007.

11 Özmenli, 2016, 521.

12 Özmenli, 2016, 522-523.

13 Özmenli, 2016, 531. 
şeklinde ifade edilmiştir. ${ }^{14}$ Samsun hariç Sinop-Trabzon arasındaki Doğu Karadeniz sahilleri ile bölgenin Orta Anadolu'ya açılan kısımlarında güçlü bir askeri güç oluşturan Çepni Türkmenlerinin Doğu Karadeniz Bölgesi’nin Türk yurdu haline gelmesindeki rolleri özellikle Çepni Türkmen beyliği Hacı Emiroğulları'nın Doğu Karadeniz Bölgesi’nin Türk yurdu haline gelmesindeki rolleri hiç şüphesiz çok mühimdir. ${ }^{15}$ Osmanlılar yöreyi aldıktan sonra 1427 yılında Hacıemiroğulları Beyliği’ne son vermiş olsa da Çepnilerin bölgedeki önemi devam etmiştir. Bolaman ve Aksu Irmaklarının sınır olduğu yöre 14551613 yılları arasında 3 parçaya bölünerek Aksu Irmağı doğusunda kalan bölge "Vilayet- $i$ Çepni” olarak adlandırılmıştır. ${ }^{16}$ Aynı dönemlerde bölgedeki bu fetih hareketlerine Doğu Anadolu'daki Türkmen aşiretleri de katılmışlardır. ${ }^{17}$

Bölgenin etnik yapılanışında Türkmenler kadar Hazar Denizi’nin Kuzey Doğu'sundan yola çıkarak Kafkasya üzerinden Doğu Karadeniz'e gelen Kuman-Kıpçak boyları da etkin olmuştur. Kuman-Kıpçak boyları, Anadolu'ya girmelerinin ardından, Kütayis (Açıkbaş), Ahıska, Kars ve Ardahan'dan başlayarak Gümüşhane’nin kuzeyi, Rize, Artvin ve Trabzon'a kadar uzanan sahil hattında ve hatta Kuzey Doğu Karadeniz sıradağları yayının güney etekleri boyunca Niksar'a kadar geniş bir alanda yer tutmuşlardır. Bölgeye gelişleri milattan önceki yüzyıllara dayanma ihtimali büyük olmakla birlikte 12 . Yüzyılın ilk çeyreğinde Gürcistan kralı David Ağmaşenebeli (1091-1125) tarafından Kütayis (Açıkbaş), Ahıska, Kars, Ardahan, Gümüşhane'nin kuzeyi, Rize ve Artvin'e yerleştirilmişlerdir. Özellikle "Kral David'in 1118 yılında 45 bin kişilik bir Kuman kitlesini aynı bölgelere yerleştirmiş olması takibeden süreçte Doğu Karadenizi Kuman/ Kıpçak boylarına açmıştır. Geçen zamanla sayıları artan ve muhtemelen Hristiyanlığı da seçen bu Kuman/Kıpçak topluluklarl, Kral David'in son zamanlarında Yusufeli, İspir bölgesindeki Oğuzları da yenerek Çoruh havzası boyunca vadilere yerleşmişlerdir. Kral David'den sonra oğlu Kral Dimitri de 1125 yılında iskân sorunlarl yüzünden isyan çıkaran Kumanları Ardahan, Oltu, Göle, Tortum, Şavşat, Ardanuç ve Yusufeli bölgelerinde iskân ettirmiştir". ${ }^{18}$ Yine aynı tarihlerde bazı Kıpçak boyları Gürcistan'dan ayrılarak Trabzon, Gümüşhane, Giresun, Torul, Alucra, Şebinkarahisar ve Ordu'ya göç etmiştir. ${ }^{19}$ Bu bakımdan "Kipçaklar, Doğu Karadeniz'in Türkleşmesinde Ŏguzlardan sonra ikinci derecede önemli rol oynamışlardır". ${ }^{20}$

16. yüzyıl Osmanlı arşiv belgelerine yansıyan şekliyle, dönemin idari yapılanışında 14. yüzyıldan başlayarak en büyük yönetim birimi Beylerbeyilik’tir. Eyalet olarak da adlandirılan Beylerbeyilikler; sancaklar ve livalara, Sancaklar ve Livalar

14 Turan, 2009, 301. Ayrica bk. Turan, 1984, 512; Sümer,1972,327-329; Sümer,1992.

15 Demir, 2005,32; İnce, 2018, 96; Sümer,1972,327-329; Sümer,1992.

16 İnce, 2018, 96.

17 Özmenli, 2016, 521.

18 Özmenli, 2016, 526.

19 Kırzıŏglu, 1992,148-181.

20 Cöhce, 1988,484. 
kazalara, kazalar nahiyeler'e, nahiyeler de karye ve mezralara ayrılmıştır. ${ }^{21}$ Giresun'dan Artvin'e kadar Doğu Karadeniz bölgesi yerleşmelerini kapsayan bölgenin idari yapılanışı ve verilen adlar ilerleyen zamanlarda değişiklikler gösterir. Bazen Doğu Karadeniz Bölgesinin topoğrafyası ile tam olarak örtüşmeyecek şekilde eyalet merkezleri ve bağlı sancaklar değişmiştir.

Hemen hemen tüm Doğu Karadeniz topoğrafyasını kapsaması bakımından çok önemli olan Trabzon ve havalisi, "1461 yılındaki fethinin ardından 1520 yllına kadar bağımsız Osmanlı idari yapılanışında bir uç beyliği olarak yönetilmiş, Daha sonra kısa sürelerle Erzincan-Bayburt ve Diyarbakır Beylerbeyliği'nin bir sancağı konumunda kalmıştır. Takiben, 1535 yllından 1580 yılına kadar Erzurum Beylerbeyliği'ne, 1581 yılından itibaren 17. yüzyılın başlarına kadar da Batum Beylerbeyliği'ne dâhil edilmiştir. 16. Yüzyll sonlarından itibaren 1650'lere kadar 'Eyâlet-i Batum nâm-ı diğer Trabzon' diye anılan Trabzon Beylerbeyliği 1650 yılından sonra da "Trabzon Eyâleti"olarak adlandırllmıştır. 1461-1600 yılları arasındaki Trabzon sancă̆ının sinırları Giresun'daki Batlama Deresi'nden Çoruh Nehri 'nin Kara Deniz'e döküldüğü Batum 'a kadar uzanır". ${ }^{22}$ Bu durum, 28 Zilkade 963 (3 Ekim 1556) tarihli bir mühimme defterine; "Feth-i Hakanî'den berû, Çoruk (Çoruh) suyundan berûsu Trabzon sancă̆ıdır..."şeklinde kaydedilmiştir. ${ }^{23}$ 1461-1600 yılları arasında idari yapılanışı bakımından en geniş haline ulaştığ 1 16. yüzyıl ortalarında, "Trabzon sancă̆l, bugünkü Trabzon ilinin bütün ilçelerini içine aldığı gibi, bugünkü Giresun'un merkez kazası ile Keşap, Dereli, Karabulduk, Yağlıdere, Doğankent, Çanakçı, Espiye, Tirebolu, Görele ve Eynesil ilçelerini,yine bugünkü Gümüşhane ilinin Kürtün ve Torul ilçeleriyle, Gümüşhane'nin merkezini içine almaktaydl. Trabzon'un fethinden itibaren bugünkü Rize ilinin bütün ilçeleri Trabzon sancă̆ına bă̆lıydı. Batum sancă̆l kurulduktan sonra bugünkü Pazar, Çamlıhemşin, Ardeşen ve Fındıklı ilçeleri adı geçen sancăga bağlanmıştır. Bugünkü Artvin ilinin Arhavi ve Hopa ilçeleri de Batum sancağına bağlanmadan önce Trabzon sancă̆ına tâbi idiler. 1878 Berlin anlaşması ile sınırlarımız dışında kalan Gönye de Batum sancă̆ı kurulana kadar Trabzon sancağına bağll bulunuyordu". ${ }^{24}$

16. yüzyılın son çeyreği ile 17. yüzyıl başlarına gelindiğinde dönemin Doğu Karadeniz bölge sınırlarını belirleyen Trabzon Eyalet sınırları; "Avârızhâne İcmal Tahrir defterlerindeki kayltlara göre Kazâ-i Trabzon, Sürmene, Giresun, Rize, Keşap, Mapavri, Kürtün, Maçuka, Of ve Görele'yi içine alan toplam 10 kazâ merkezine 1583-1600 yllları arasında ilave olunan Keşap, Tirebolu, Yavabolu nam-i diğer Görele, Maçka(Maçuka) ve Içil nam-ı diğer Yomura kazâlarının da kurulmasıla genişlediği görülürr". ${ }^{25}$

21 Bostanc1, 2007.

22 Demirci-Saraç, 2012,3;Bostan 2002,46.

23 Bostan 2002,48.

24 Bostan 2002,48,49.

25 K1lıç, 1999, 179-192; Demirci, 2012,19. 
Osmanlı İdarî teşkilatı açısından bakıldı̆̆ında Trabzon Eyaleti 19. Yüzyılın ortalarına ulaşıldığında, "merkez sancağı, Karahisar-ı Şarkî (Şebinkarahisar), Canik, Gönye ve Batum sancaklarını kapsamaktaydl. Bu idarî yapının genel düzeni 19. Yüzyılın sonlarına kadar çok fazla değişmeden devam etmiştir. Burada önemli olarak zikredilebilecek değişiklikler Batum sancă̆ının adının 1852'de Lazistan sancă̆ı şeklinde değiştirilmesi, Batum'un kaybedilmesinden sonra da sancak merkezinin Rize’ye taşınmasıdır. Ayrıca Canik sancağı bir süre ayrı bir mutasarrıflk olarak idare edilmişse de genelde merkez vilayete bağlı kalmıştır. 1864 Vilayet Nizamnamesi bu bölgede uygulanmaya başlandı̆̆ında vilayete merkez sancă̆l ile birlikte Batum, Canik ve Gümüşhane sancakları dâhildi. Bu dönemde Çarşamba, Of, Tirebolu, Sürmene, Ordu belli başlı merkezler olarak dikkat çekmektedir. 19. Yüzyılın ilk yarısında tarihte olduğu gibi bütün bir Doğu Karadenizi kapsayan Trabzon eyaleti, 1864 yılında eyâletlerden "Vilâyet" sistemine geçilmesinden sonra idari taksimatı diğer vilâyetlerin kurulup 1870 yılında bu idarî birimlere Nâhiye teşkilatlarının ilave edilmesiyle bölgedeki idari taksimat günümüzdeki şekline yakın bir yapılanış kazanmıştır."26

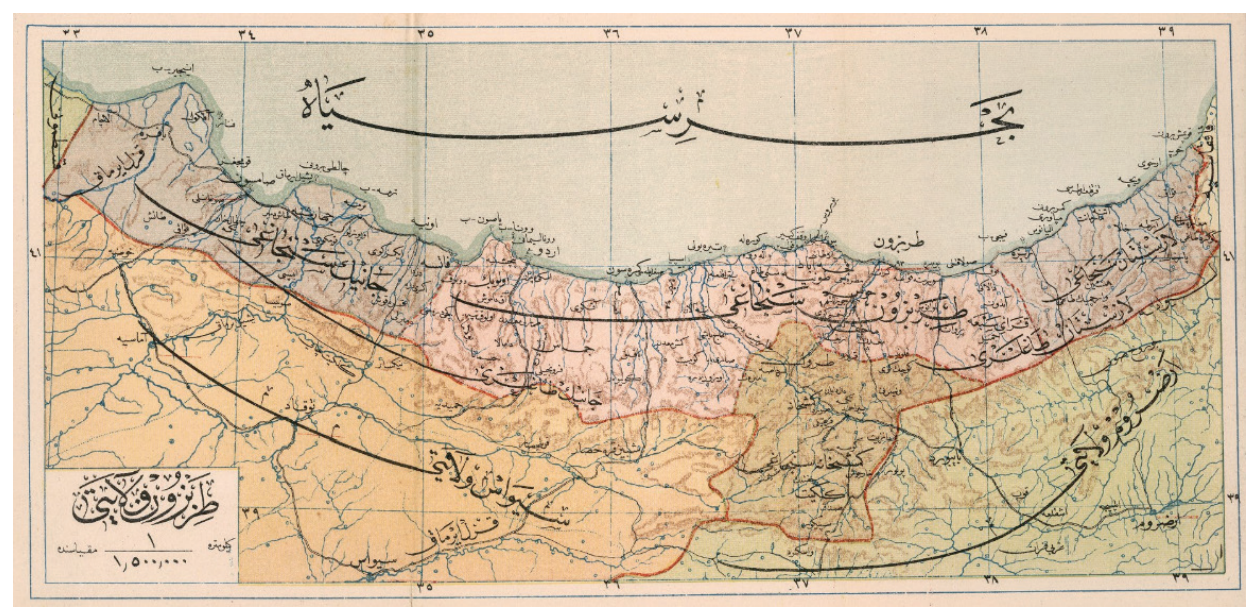

Harita 3: Doğu Karadeniz Haritası (Vilayet-i Trabzon), (Mehmet Rüştü-Mehmet Eşref-Mehmet Nasrullah. (H.1325/M.1909). (Rumsey, a)

\section{Yollar- Zaviyeler- Derbendler}

\section{Kadim Yollar}

İlk izleri, antik çağa kadar uzanan Anadolu ticaret yolları, Osmanlı Döneminde, Selçuklu Çağı yol sistemini aynen kullanmakla birlikte doğuya ve batıya devam eden üç ana güzergâhtan oluşmaktaydı. Sağ, sol, orta kol olmak üzere bu üç ana güzergâh da

26 Demirci-Saraç, 2012,3. 
yan yollara ayrılmıştı. İstanbul merkez olmak üzere Anadolu yollarının üç güzergâhının ilki Anadolu'nun güneyinden İstanbul-Şam arasında, ikincisi Orta Anadolu üzerinden İstanbul-Bağdat arasında, üçüncüsü de İstanbul-Erzurum-Tebriz arasında işleyecek şekilde düzenlenmişti. ${ }^{27}$ Konumuz açısından, İstanbul/Üsküdar-Bolu-Tosya-MerzifonNiksar-Karahisar-Kelkit-Aşkale üzerinden Tebriz'e ulaşan Kuzey Anadolu tarihi ticaret yolu, Doğu Karadeniz'e açılan bağlantılarıyla önemlidir. Trabzon'dan hareketle aynı istikametteki bir başka yol da, Pyxites suyu/Değirmen çayı/Değirmendere üzerinden, Palima kalesi/Hamsiköy, Zigana geçidindeki Zavena kalesi, ardından Ardasa kalesi/ Cadaca, Ardaça/Torul, Dorila kalesi/Dorileh, Orilla (Torul yakınında), Alanza köyü/ Alansa, Gümüşgöze köyü (Kelkit yakınında), Gümüşhane, Bayburt ve Erzurum üzerinden yine Tebriz'e ulaşırdı. ${ }^{28} \mathrm{Bu}$ yol, Karadeniz sahilindeki yerleşmelerle bu yerleşmelerdeki ticaret odakları olan limanlara Kuzey Doğu Anadolu sıradağları arasından geçit veren yan yollarla bağlantılıydı. Bölgenin tarihine ilişkin belge ve kalıntıların işaret ettiği noktaların birleştirilmesiyle ortaya çıkan bu yan yollar, sahilden güneye yani Orta ve Doğu Anadolu'ya açılan vadilerde, yedisi dikey, ikisi ise yatay olarak gelişmişti. ${ }^{29}$

Transit ticaret yol ağında olmayan Artvin hariç, Karadeniz şehirleri ve limanlarıyla Erzurum üzerinden Doğu Anadolu'yla bağlantı kuran, İstanbul-Tebriz arasındaki Kuzey Anadolu transit ticaret yolu ve bağlantılı ara yollar üzerindeki menziller boyunca küçüklü büyüklü çok sayıda köprü bulunur. Bu köprüler ve doğu Karadeniz’in batı sınırlarındaki Şebinkarahisar'dan başlayarak, Alucra, Şiran, Kelkit, Bayburt, Aşkale, Erzurum transit güzergâhına Karadeniz sahillerinden yol veren vadilerdeki ara yollar yüzlerce yıl bu sistemin işleyişini sağlayan derbendçi, köprücü zaviyeler tarafından işler tutulmuştur.

Muhtemelen Türklerin Anadolu’ya gelişlerinden önce de kullanılan İstanbul/ Üsküdar-Bolu-Tosya-Merzifon-Niksar-Karahisar-Kelkit-Aşkale üzerinden Tebriz'e ulaşan tarihi Kuzey Anadolu ticaret yoluna "XVI. yüzyılın sonu ve XVII. yüzyılın başlarında, alternatif, paralel bir hat daha geliştirilmiştir. Bu hat İstanbul'dan Amasya'ya, oradan Niksar, Koyulhisar, Şebinkarahisar üzerinden Kelkit Çayı boyunu takip ederek Kelkit ve Otlukbeli (Karakulak)'ne ulaşan yol idi. Eski güzergâhla bu yol arasında, Erzincan'ın kuzeyindeki Esence (Keşiş) Dağları sıralanıyordu." ${ }^{\prime 3}$

Yukarıda da ifade edildiği gibi ilk örneklerinin nerede ve ne zaman kurulduğu bilinmemekle birlikte, tahrir defterlerine yansıdığı kadarıyla bu ana ve tali güzergâhlarda 16. Yüzyılın ortalarından itibaren yollar boyunca, ihtiyaca veya topoğrafyaya bağlı olarak palanka $^{31}$, imarethane/misafirhane, köprü, mescit, çeşme gibi yapılardan oluşan vakıf

27 Halaçoğlu, 1995, 14; Bostan, 1993, 65; Miroğlu, 1997, 241.

28 Eskikurt, 2014, 28.

29 Fatsa, 2014, 38.

30 Gündoğdu, 2001,66.

31 küçük kale, karakol. 
Harita 4:

19. yüzyılda Şebinkarahisar Giresun güzergâh1. (Tosun, 2016,11)

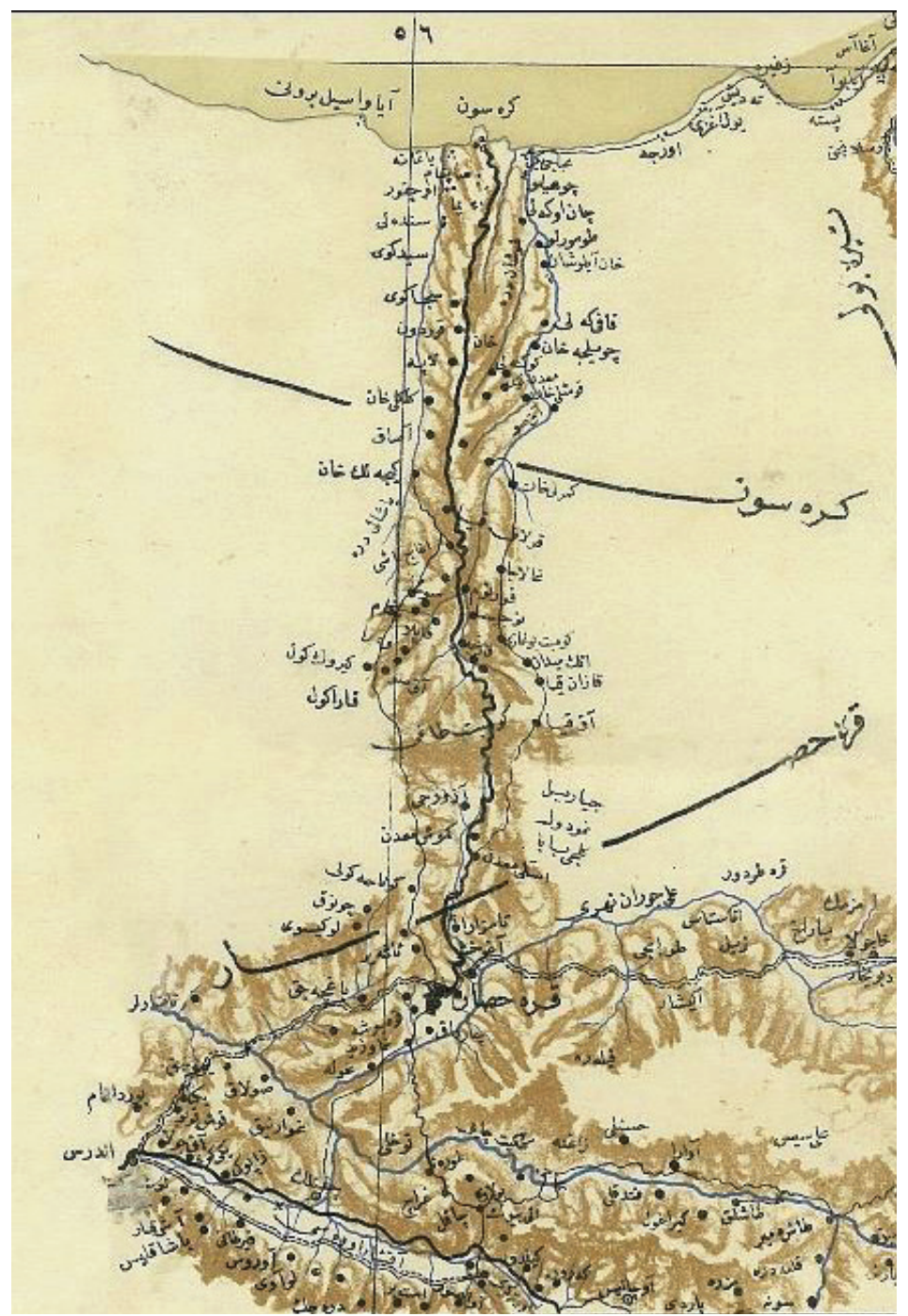

zâviyeler şeklinde külliyeler kurulmuştur. ${ }^{32}$ Örneğin, Karadeniz Bölgesi'nin fethinde rol almış ve daha sonra Giresun Merkez Duroğlu Beldesi Tekke köyü'nde derbend hizmetiyle ilgili zâviye kurmuş, Ahi liderlerinden Yakup Halife zâviyesi ve bu zaviyeden söz eden Başbakanlık Osmanlı Arşivi'deki (BOA) ${ }^{33}$ Trabzon Sancağına ait Maliyeden

32 İnalc1k, 2003, 153.

33 Devlet Arşivleri Başkanlığı, 16 Temmuz 2018 tarih ve 30480 sayılı Resmi Gazete'de yayınlanan kararname ile kapatılarak Cumhurbaşkanlığı Devlet Arşivleri Başkanlığı kurulmuştur. 
Müdevver 828 numaradaki 1486 tarihli tahrir defteri bu konudaki tespite kaynaklık eden ilk kayıtlardan birisidir. ${ }^{34}$ Bu sistem içinde özellikle derbend görevi gören zaviyeler sarp geçitlerdeki yollarda güvenlik ve barınma hizmetlerini, buralardaki köprülerin bakım ve onarım hizmetlerini yanı sıra çevrelerindeki yerleşim alanlarında kendilerine devletçe verilen diğer kamu hizmetlerini yapmışlardır.

\section{Derbendler}

14. yüzyılda, Beylikler Dönemi’nde kısmen bozulan yol, köprü ve geçitlerin güvenliğini sağlamak için kurulan sistem, daha sonraki yüzyıllarda merkezi otoritenin tekrar sağlanması ve "derbend"35 teşkilatının kurulması ile beraber uzun yüzyıllar boyunca sürdürülmüştür. Kervanları, yolları ve köprülerin güvenliğini sağlamak için kurulan İlhanlı "tutkavu" sistemiyle benzerlikler gösteren derbend teşkilatı, 14. yüzyılın sonlarında kurulmaya başlanmış, Osmanlı döneminde II. Murat'ın saltanat yıllarında bir kurum olarak ortaya çıkmıştır. ${ }^{36} \mathrm{Bu}$ tarihten sonra, Osmanlı Devleti'nde ulaşım işlerini düzenleyen özel bir teşkilat bulunmadığından yol-köprü yapımı, tamiri ve güvenliğinden devletin teşkilatlandırdığ köprücüler sorumlu tutulmuşlardır. ${ }^{37}$ Derbend görevi gören zaviyeler özellikle ticaret yolları üzerindeki vadi geçişlerine kurdurularak, ticaret hayatının güvenlik içinde gerçekleşmesi sağlanmıştır. ${ }^{38}$ Yanı sıra bulundukları çevrede toplumsal dayanışma, birliktelik ve güvenlik konularındaki hizmetler ile yerleşik iş hayatı ve toplumun diğer sosyal ihtiyaçlarını karşılamışlardır. ${ }^{39}$

Derbend tesisleri; içinde, han, mescid, ticarethaneler olan etrafı duvarlarla çevrili karakollar şeklindeki küçük külliyeler veya kalelerdir. Genellikle yolların birleştiği noktalara ve geçitlere kurulan derbendliklerde görev yapanlar, "bu kuruluşlara mensûp hizmet erbabl, amme hizmeti gördükleri için birtakım örfi rüsûmdan (vergilerden) (avârız-ı dîvaniyye, tekâlîf-i örfiyye vb.) muaf tutulurlardı". ${ }^{40}$ Derbendler yollar, geçitler ve köprülerin güvenliğinin sağlanması için önemli olmakla birlikte, yeni yerleşim alanlarının iskâna açılması için de kullanılmıştır. "Derbendlikler, kuruluş şekilleri bakımından ikiye ayrllır, yurtluk ve ocaklık şeklinde tımar yoluyla veya muafiyet usulüyle verilirdi. Görevleri bakımından da; derbend mahiyetindeki kaleler, büyük vakıf şeklindeki Derbend tesisleri, han ve kervansarayların derbend olarak kullanilmasi ve derbend köprücüler olmak üzere dörde ayrllırlardı. " 41

34 Bostan, 2013, 49; Fatsa, 2014, 44.

35 Derbend / دربند ; derbendçi / دربندى. Bk. Şemseddin Sami, 2015, 604.

36 Halaçoğlu, 2003, 162.

37 Güçer, 1987, 9; Orhonlu, 1984, 27; Orhonlu, 1990; Miroğlu, 1997, 245; Yücel, 1988.

38 Tosun, 2016,200,201.

39 Barkan, 1942, 301.

40 Şentürk, 2002, 1673.

41 Halaçoğlu, 1994,162; Ersoy, 2008, 51. 


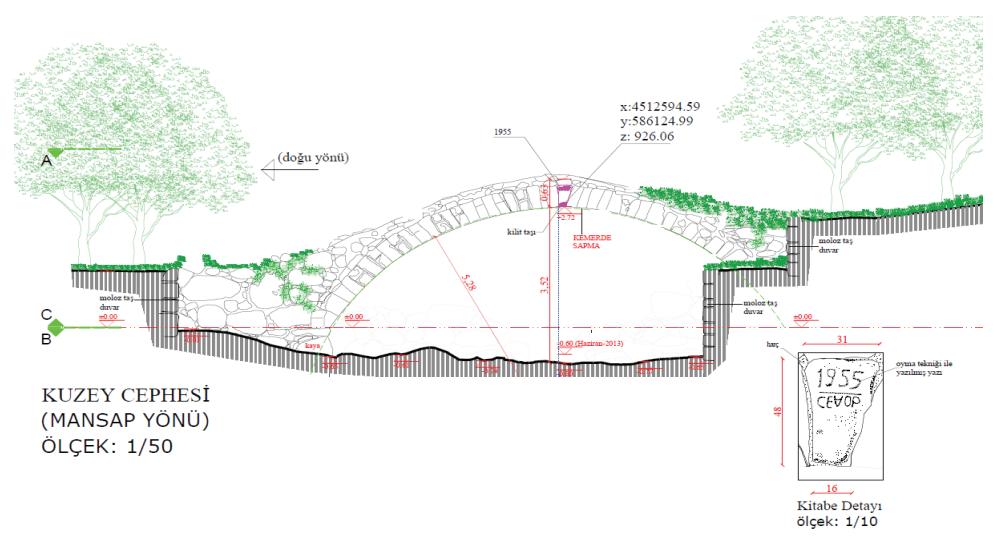

Şekil 1: Hafızlar Köprüsü, Kuzey Cephe Rölöve Çizimi. Yeşilyurt Beldesi, Araklı, Trabzon. (Dilaver vd, 2013'ten işlenerek).

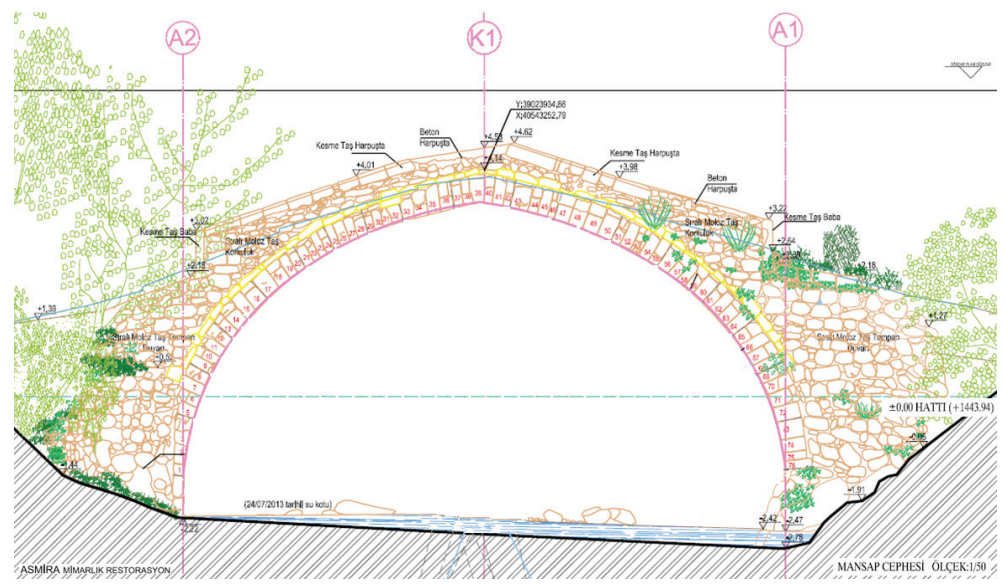

Şekil 2: Sarıbaba Köprüsü, Kuzey Cephe Rölöve Çizimi. Kürtün, Gümüşhane. (Emek, 2014’ten işlenerek)

Bir köprünün de olduğu önemli güzergâhlardaki vadi geçişlerinde bulunan derbendlerde görevliler derbendçilik yanısıra köprücülük ve menzilcilik de yaparlardı. Anadolu'da ve Balkanlarda Müslümanların yanı sıra Hristiyanlara da derbendlik verilir bunlara 'martolos' denirdi. Askeri bir yapılanmanın söz konusu olduğu derbendlerde ünvanlar; Başbuğ, sağ kolağası, bölükbaşı, sol kolağası, zabitan ve neferler gibi askeri 
idi. Ancak askeri kuvvetin bulunmadığı derbendler de bulunduğundan buralarda görev yapanlar han ağası veya derbend ağası, derbendçibaşı, derbendçi bölükbaşısı gibi sivil unvanlar taşırlard1. ${ }^{42}$ 17. Yüzyıldan itibaren bozulmaya başlayan derbend teşkilatı, 18. Yüzyılda tımar sisteminde yaşanan uygulama sıkıntıları, çift bozma gibi problemler nedeniyle 19. Yüzyılın sonlarına doğru ortadan kalkmıştır.

\section{Zaviyeler}

12.-13. yüzy1llarda ilk Türkmen iskân bölgelerinden birisi olan Giresun ve çevresi Doğu Karadeniz'de zaviye örgütlenmesinin en yoğun olduğu yerler arasındadır. Bu konuda günümüze ulaşan en eski kayıtlar da bu bölgedeki yerleşmeleri kuran öncü fatihlere ve kurdukları zaviye vakıflarına aittir. Giresun sahilden başlayarak Dereli'den geçen, Şebinkarahisar'a ulaşan güzergâh üzerindeki Şeyh Mustafa, Hacı İlyas, Şeyh Süleyman ve Yakup Halife zâviyeleri, Dereli ilçe merkezi yakınında bulunan Kuşluhan Kalesi ve yöredeki köprüler bölgenin batısındaki yol sistemi içinde kalan önemli zâviyelerdir ${ }^{43}$

Bölgedeki bu zâviler içinde de, Karadeniz Bölgesi’nin fethinde rol almış ve daha sonra Giresun Merkez Duroğlu Beldesi Tekke köyü'nde derbend hizmetiyle ilgili zâviye kurmuş, Ahi liderlerinden Yakup Halife zâviyesi bu konudaki en erken örneklerdendir. Başbakanlık Osmanlı Arşivi (BOA) 'nde bulunan "C.ML.229/9589-27 numara ile kayıtlı Rebiyyülahir 1239 tarihli bir belgede sözü edilen, Şebinkarahisar-ÇamolukŞiran-Erzurum Güzergâhı üzerinde Zıhar mevkiindeki Feygas ve Zıhar zaviyeleri" ${ }^{44}$ ile Hacı Abdullah Halife, Boynuyoğun (Kasım Dede), Melik Ahmed Bey, Derviş Murad ve Menteşe zaviyeleri de bölgedeki diğer önemli zaviyelerdir. ${ }^{45}$ Yakup Halife zaviyesinden "Karye-i Kurâba (Guraba), vakf-ı Süleyman Bey, zâviye-i Yakup Halife" şeklinde söz eden Başbakanlık Osmanlı Arşivi'deki Trabzon Sancağına ait Maliyeden Müdevver 828 numaradaki 1486 tarihli tahrir defteri ifade edildiği gibi bu konudaki en eski kayıttır. ${ }^{46}$ Merkez Duroğlu Beldesi Tekke köyünde Yakup Halife'nin adıyla anılan türbesi, bir değirmen ve tek açıklıklı bir köprü de günümüze ulaşmıştır. ${ }^{47}$

Mükerrer olarak 1515 ve 1530 tarihli tahrir defterlerinde yer alan kayıtlarda Yakup Halife vakfına dahil olan köyler, mezralar ve tarihi yol ile derbend hizmetinden söz edilerek, Yakup Halife vakfının yıllık 2.067 akça gelirin, Arpa, Iklıkçı, Guraba, Çatak,ve Eğrigeriş adlı köyler ile Çatak Deresi üzerinde bulunan üç su değirmeni ve

42 Halaçoğlu, 1994,163.

43 Fatsa, 2014, 44.

44 Tosun, 2016, 201.

45 Bostan, 2013, 48.

46 Bostan, 2013, 49; Fatsa, 2014, 44; Giresun merkez Duroğlu beldesi, Tekke köyü'ndeki türbesi TKVKBK'un 19.03.1992 gün ve 1309 sayılı kararı ile kültür varlı̆̆ 1 olarak tescillenmiştir.

47 Duroğlu beldesi, Tekke köyünde, 456252-4518475 koordinatlarında bulunan kemer köprü ve 456727-4518538 koordinatlarında bulunan değirmen TKVKBK tarafından 29/02/2012 gün ve 304 sayılı kararı ile tescil edilmiştir. 
bir şahin yuvasından elde edildiği yazmaktadır. ${ }^{48}$ Giresun merkeze bağlı Mesudiye köyü Çatak Mahallesi köprüsü ${ }^{49}$ ile Şalaklı Köyü, Çömlekçi Köprüsü ${ }^{50}$ ve Çiçekli Köyündeki değirmen ${ }^{51}$ Yakup Halife zaviye ve vakfı yapılarından olmalıdır. Yakup Halife hakkındaki bir başka tahrir kaydında da, bölgenin fethine katıldığı için kendisine beş köy vakfedildiği ve kendisinden akrabaları ile buralara yerleşip, yapacakları zâviye ve cami ile buradan geçen kafilelere yol hizmeti vermeleri istendiği yazmaktadır. ${ }^{52}$ Yakup Halife zâviyesinin sorumluluğunda olduğu anlaşılan Barça köyünün derbend görevinden bahseden bir başka tahrirde de, Barça Köyü halkından 19 kişiye Derbende bağlı köprülerin ve yolların bakım ve onarımı ile güvenlik işlerinin verildiği anlaşılmaktadır. ${ }^{53}$ Yine aynı defterde, bölgedeki Çalış köyünün, yakınlarındaki Söğüt Köprüsü’nü atlı ve yaya geçecek şekilde bakım ve onarımını yapmakla, Dereli köyünden de iki kişinin derbend muhafızlığı yapmakla sorumlu tutuldukları yazmaktadır. ${ }^{54} \mathrm{M}$. Fatsa'nın 1530 ve 1554 tarihli kayıtlı bir başka tahrir defterinden aktardığına göre, Yenicehisar, Sarvan, Göveç, Alınyoma ve Kaba köylerinde oturan halkın bir kısmı da derbenci yazılarak, Yakup Halife Derbendi ile bağlantılı Vanazıd (Keşap ilçesinde bir mahalle), Kızılöz ve Şemseddin (Bulancak’ta birer mahalle) Derbendi gibi başka yol ve güvenlik sistemleri içinde görev almışlardır. ${ }^{55}$

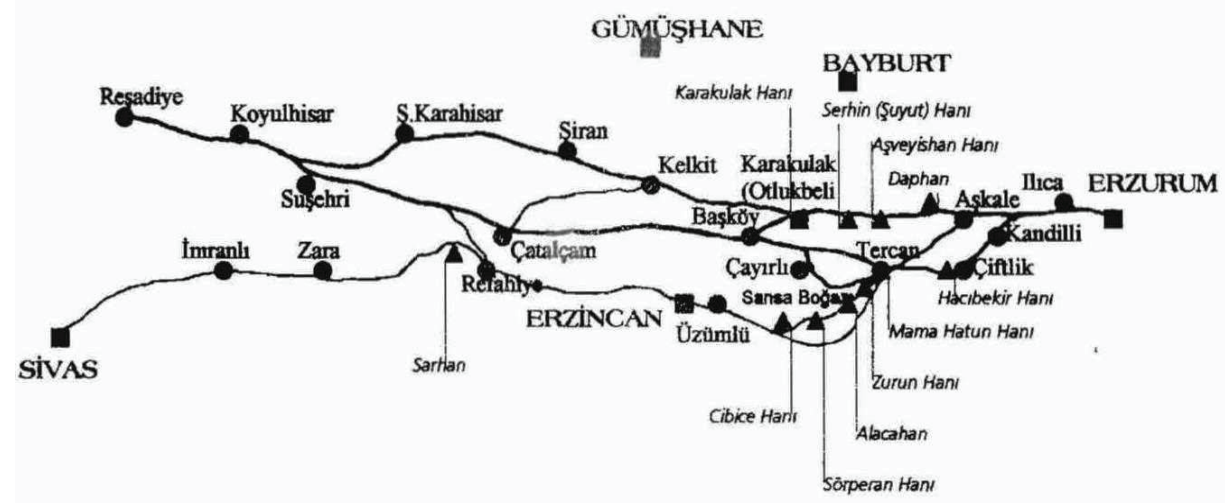

Harita 5: Kuzey Anadolu transit geçişi ve yan bağlantı yolları. (Gündoğdu, 2001,69)

48 Fatsa, 2014, 44.

49 TKVKBK Tescil Karar No: 30/05/2014-1827

50 TKVKBK Tescil Karar No: 28/01/2015-2192

51 TKVKBK Tescil Karar No: 17/07/2014-1912

52 Fatsa, 2014,45.

53 Fatsa, 2014,45.

54 Fatsa, 2014,45.

55 Fatsa, 2014,45. 


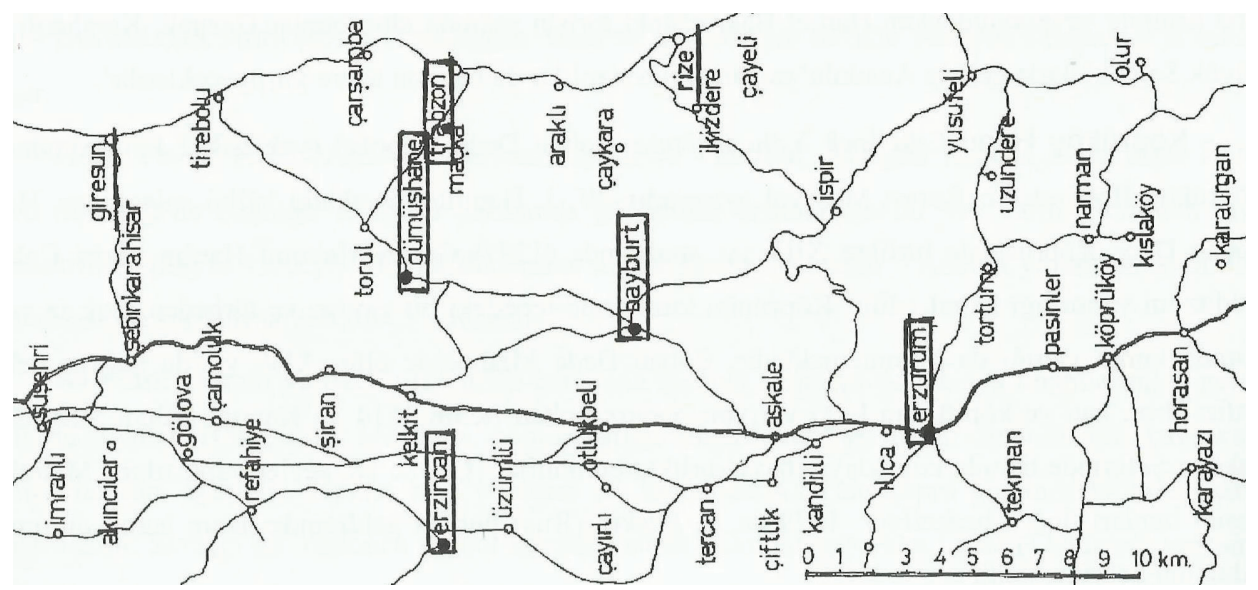

Harita 6: Doğu Karadeniz vadilerine yol veren Kuzey Doğu Anadolu yol güzergâhı.

(Tuncer, 2007, 126)

Aksu vadisi boyunca, Giresun-Dereli-Şebinkarahisar güzergâhındaki, Yavuz Kemal Beldesindeki Şeyh Mustafa, Kızıltaş Köyündeki Hacı İlyas ve Sarı Yakup köyündeki Hamza Şeyh Zâviyeleri de bölgenin yol ve derbend sisteminden söz eden kayıtlarda geçmektedir. Örneğin, 1613 tarihli bir tahrir kaydında Hacı İlyas zâviyesi mensuplarının Dereli köprülerinin onarımını yaptığı yazmaktadır. ${ }^{56}$

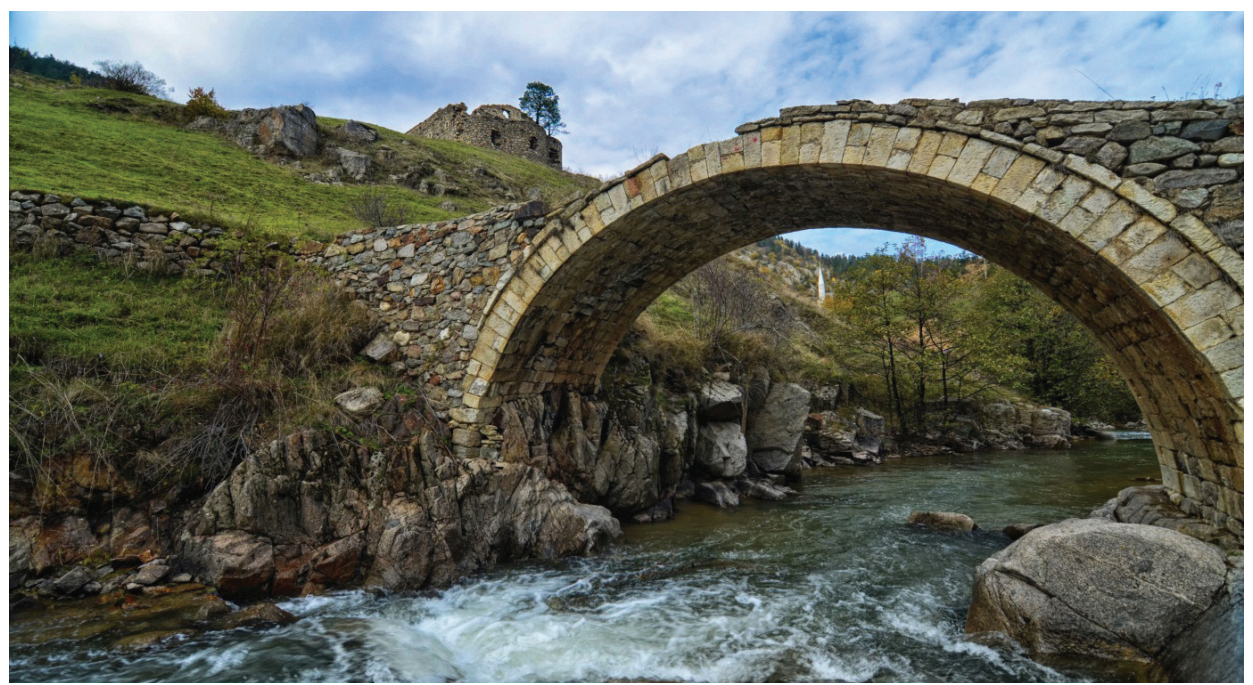

Fot. 1: Çakrak Yaylası Köprüsü. Yağlıdere - Giresun.

(Trabzon Kültür Varlıkları Koruma Bölge Kurulu, 2017)

56 Fatsa, 2014,45. 
Giresun sahilinden başlayarak Dereli-Şebinkarahisar güzergâhını oluşturan Aksu vadisinin doğusundaki paralel akarsu olan, Yağlıdere'nin açtığı vadiyi denizden gelecek tehlikelere karşı koruyan Andoz (Eşik Kale) Kalesi ile başlayıp güneye vadi boyunca devam eden Yağlıdere vadisi, Şebinkarahisar'a ulaşan, Yağlıdere Ağa Köprüsü, Sınır Köprüsü, Zabunlu Köprü, Harava Köprüsü, Koçlu Köprüsü, Kızıllar Hanı, Ahiçukuru Köyü, Kozbükü Hanı, Sınır Hanı, Çakrak Yaylası ve Köprüsü, Saydere Yolu, Avutmuş menzillerinden oluşan bir yol güzergâhına sahipti. "Hafizalardan silinmeye yüz tutmuş olan bu güzergâh, yolu işaret eden köprüler, çeşmeler ve taş döşemelerin bir kismı ile günümüze kadar gelebilmiştir". ${ }^{57}$ Tahrir defterlerinde "Yağlıdere Derbendi" olarak anılan bu yol sistemi içindeki vadide günümüze ulaşan 12 kemer köprünün kitabeleri olmadığ1 için yapım tarihleri bilinmemektedir. Ancak bu yapılardan Alucra karayolu güzergâhındaki Yağlıdere üzerinde, Yağlıdere ilçe merkezine 3,5 km mesafede, Ümit Bükü Köyü yakınındaki Ağa köprüsü H.1232/M.1816/17 yılında Tirebolu Voyvodası Kethüdazade Mehmed Emin Ağa tarafından yaptırılmıştır. ${ }^{58}$ Yağlıdere Alucra yolu üzerinde önemli bir menzil olan Çakrak Köyü ve Yaylasında bulunan üç köprü ${ }^{59}$ de Yağlıdere Derbend sisteminin önemli bir parçasıdır. Bu köprülerden ilki köy içindedir. İnce yonu andezit taşla yapılmış yarım dairesel tek kemerli köprünün bugüne ulaşan bir kitabesi yoktur. Fazla su toplamayan bir akarsu yatağına yapıldığı için muhtemelen 19. Yüzyıl sonunda yapıldığı özgün haliyle günümüze ulaşmıştır. Köydeki diğer bir köprü Yağlıdere Alucra yolunun Alucra çıkışındaki geç 19. Yüzyıl Ortodoks kilisesine ve Çakrak yaylasına yol verir. Yarı dairesl tek kemerli ve her iki yana eğimli bu köprünün de kitabesi yoktur. Ancak, köydeki dört kilise ile üç köprü aynı dönemlerde inşa edilmiş olabilir. İkinci köprü yönünde Çıkrıkkapı ayrımındaki son köprünün de kitabesi yoktur. Diğerlerinden farklı olarak sivri tek kemerli olarak inşa edilen taş köprü belki de diğerlerinden daha geç bir örnektir. Bu güzergâhtaki köprülerin inşasına ilişkin bilinen en eski kayıt, Espiye yakınındaki Andoz Kalesi yakınında yerleşik olan 13 kişinin Yağlıdere Derbendi yanında çalışarak Yağlıdere üzerine köprüler inşa etmeleri hususundaki görevlendirilmelerinden söz eden 1515 tarihli bir tahrir kaydıdır. ${ }^{60}$ Bir başka tahrir kaydında bu görevin sonraki zamanlarda da sürdüğü anlaşılmaktadır. ${ }^{61}$

Doğu Karadeniz Dağlarının Trabzon ilinde bulunan kısmı, güneyden kıyıya paralel olarak üç blok hâlinde uzanır. Bunlar, Değirmendere Vâdisi’nin batısındaki Zigana Dağları, Değirmendere ile Solaklı Çayı arasındaki Trabzon Dağları ve Solaklı Çayının doğusundaki Soğanlı Dağlardır. Karadeniz’e doğru uzanan derin vâdilerle parçalanmış olan bu dağlar üzerindeki en önemli yol Trabzon ile Doğu Anadolu arasındaki tarihi karayolu bağlantısını sağlayan Zigana Geçididir. İlk çağdan bu yana önemli bir liman olan Trabzon ve yakın çevresindeki kalelerdeki kolonilerin iç kesimlerle bağlantısı bu vadiler

57 Fatsa, 2014,46.

58 Tescil,TKVKBK Karar No:11.06.1997-2859. 20.10.1998 / 3270.

59 Tescil,TKVKBK Tescil Karar No:24/04/2008-1569

60 BOA, Tapu Tahrir Defteri, Defter No 52: 698.

61 BOA, Tapu Tahrir Defteri, Defter No 288: 593; 387-753'den aktaran, Fatsa, 2014,46. 


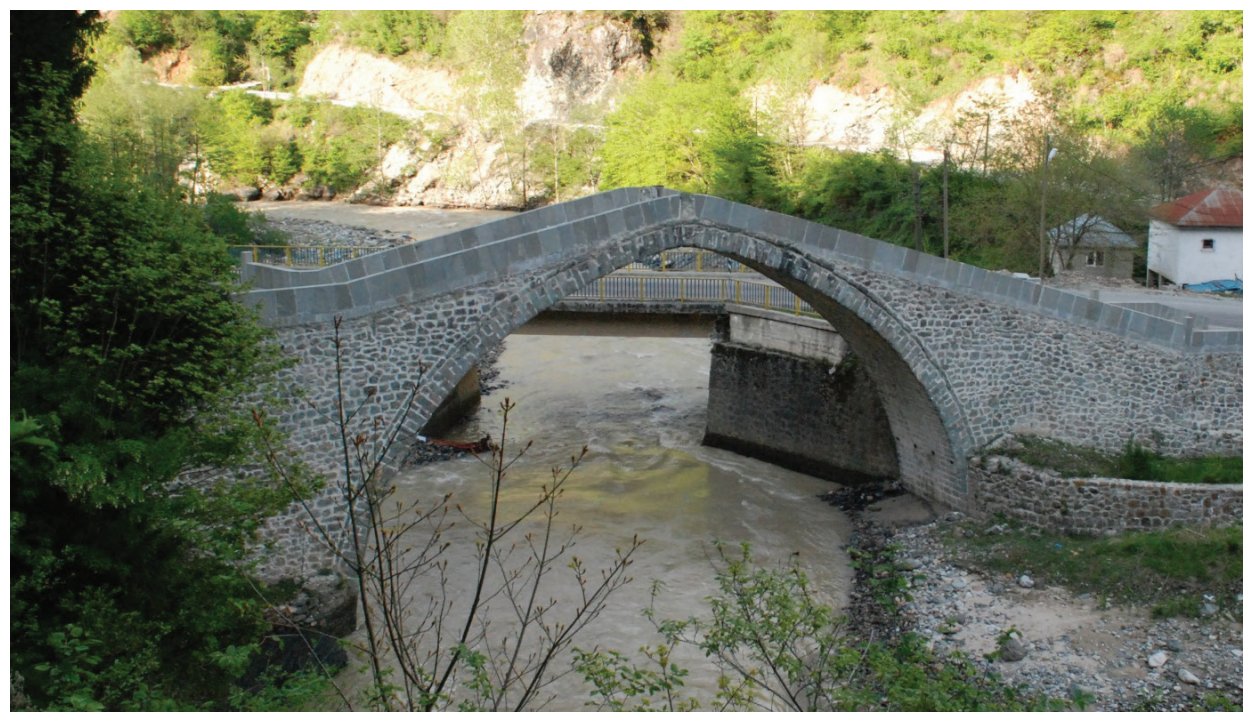

Fot. 2: Ağa köprüsü. Yağlıdere, Giresun. (TKVKBK, 2017)

boyunca yan yollarla sağlanmıştır. Trabzon - Sürmene - Bayburt, Trabzon - Dernekpazarı - Çaykara - Bayburt ve Cevizlik - Maçka - Zigana güzergâhları Trabzon bölgesindeki zâviye ve derbendler tarafından açık tutularak devamlılığı sağlanmıştır. ${ }^{62} \mathrm{M}$. H. Bostan, bölgedeki derbendlerin aktivitesinden söz ederken, 1583 tarihli bir tahrir kaydında, Trabzon Maçka arasındaki yol üzerinde bulunan derbend ve köprülere 21 köyün köprücü ve derbendçi yazıldığını, Trabzon-Canca/Gümüşhane-Erzurum yolu üzerindeki Torul'da da 800 derbendçi ve 169 da köprücünün bulunduğunun yazıldığını ifade eder. ${ }^{63}$

Trabzon Sancağı'na ait ulaşılabilen en eski tahrir kaydı BOA'deki Maliyeden Müdevver 828 numaralı 1486 tarihli defterdir. Aynı sancağa ait ilk şer'iyye sicili de 1555 yılına aittir. Yani Trabzon ve etrafındaki yerleşmelerle Doğu Karadeniz vilayetlerine ilişkin tarihi arşiv belgeleri oldukça geç tarihlidir. Bu durum, Trabzon ve çevresinin yani doğu Karadeniz'in, M.T. Gökbilgin'in, "imparatorluk kadrosu içinde; idari, askerî ve malî bakımlardan daha fazla önem kazanmasl, kendi mevcudiyetini hissettirmesi, devlet merkezinin dikkat ve alâkasını üzerine çekmesi, Bayezid II. devrinde ve şehzade Selim 'in buraya sancak beyliği ile gönderilmesi suretiyle başlamış gibidir." ${ }^{6}$ ifadesiyle açıklanabilir. Bu bakımdan 16. Yüzyıl başından itibaren kayda geçen Doğu Karadeniz bölgesinin dönemin Osmanlı devletinin idari yapılanması içindeki sınırları ve bu sınırlar içindeki vilayet ve kazalar konunun sınırlarını belirleyeceğinden belirtilmesi gerekli önemli bir husustur.

62 Bostan, 2012,155.

63 Bostan, 2002, 299.

64 Gökbilgin,1962, 293. 
Fatih Sultan Mehmet'in Trabzon'u alışının ardından batıda Canik vilayetinden başlayarak Çoruh nehrinin denize döküldüğü Batum'a kadar olan bölge Safevî Devleti ile 1639'da imzalanan ve bugünkü Türkiye - İran sınırını belirleyen “Kasr-ı Şirin” barış antlaşmasına kadar Osmanlı idari yapısı altında farklı teşekküllerle ve farklı adlarla anılmıştır. Akkoyunlu devleti, ile Osmanlı devleti arasında 1473 yılında yapılan Otlukbeli Savaşı sonrasında 15. Yüzyılın ikinci yarısında, Amasya, Tokat-Sıvas, Sonisa-Niksar,ve Karahisar-1 Şarkî (Karahisar-1 Hasan draz), Canik livalarından oluşan idari yapılanmaya “ Vilâyet-i Rum-ı Kadîm" denilmiştir. Anadolu'daki beş eyaletten biri olan bu "Rûm (Sivas) Eyaletine" zaman zaman Çorum, Malatya, Divriği/Darende, Gerger, Trabzon, Kemah (Erzincan'la birlikte), Bayburt, Tercan, İspir Erzurum dahil edilmiş, H. 970 (15621563) yılından sonra Giresun'un doğu kısmında yer alan Aksu vâdisinden başlayarak Çoruh/Kelkit vadisine kadar olan sancaklar Rûm Beylerbeyiliği’nden ayrılıp, Erzurum Beylerbeyiliği'ne katılmıştır.

BOA'da 52 numaradaki 1515/1516 tarihli Trabzon Sancağı mufassal tapu tahrir defterinin Trabzon şehri ve çevresindeki köylere ait bilgilerin bulunduğu bölümü günümüze ulaşmadığı için 1530 tarihine kadar Trabzon merkezi ve yakın çevresinde kurulan zâviyeler hakkında bir kayıt yoktur. Ancak, 1530 tarihinden sonraki tahrir kayıtlarında, Trabzon ve çevresindeki yerleşim alanlarının iç bölgelerle bağlantısını sağlayan yollar üzerine bir takım vakıf hanlar ve imaretler tesis edildiği, ayende ve revendeye hizmetin bu kurumlar eliyle sunulduğu yazar. Bu kapsamda, Trabzon'daki Gülbahar Hatun İmareti, İskender Paşa ve Mahmud Ağa hanları ile Hasan Baba, Derviş Ali, Kurban Abdal, Hızır Abdal ve Odabaşı Sinan Bey zâviyeleri dönemin ulaşım sistemine katkısı olmuş vakıf kurumlarıdır. ${ }^{65}$

Yine kaynaklarda, Kanuni Sultan Süleyman'ın saltanat yıllarının ortalarında, Trabzon ve yakın çevresinde yer almakla birlikte yukarıda söz edilen derbend, köprücü ve menzilci görevlerinin dişında faaliyet gösterdiği anlaşılan:"Zâviye-i A ğçakala, tâbi-i karye-i Kordil, der tasarruf-ı Derviş Hamza. / Zâviye-i Kurban Abdal, der Meydan ki, der tasarruf-ı veledeş. / Zâviye-i Sinan Beğ, ser-oda, der nezd-i Cami-i Cedid, der tasarrufDede Fakih/Zâviye-i Kalenderhâne, der tasarruf-ı Derviş Ali. / Zâviye-i Hızır Abdal, der nezd-i Cami-i Cedid, der tasarruf-ı Hacı Arab. / Zâviye-i Măgara, der bâlâanmahalle-i Çömlekçi, der tasarruf-ı Derviş Mehmed. / Zâviye-i Hızırlık, der sûy-ı Meydan-ı Çömlekçi, der tasarruf-ı Hızır bi hisse-i Derviş Ali” zaviyeleri kaydedilmiştir. $^{66}$

Cumhuriyet kurulana kadar farklı idari yapılanmalar geçiren bölge, 20 Nisan 1924 tarih ve 491 sayılı "Teşkilat-ı Esasiye" Kanunu ile 20.01.1921 tarih ve 85 sayılı Teşkilat-1 Esasiye Kanunu’nda değişiklikler yapılarak, sancak (liva) teşkilatı tamamen kaldırıldıktan sonra, çalışma alanımızı da oluşturan Giresun, Trabzon, Rize, Gümüşhane ve Artvin illeri idari yapılanışı şekillenmiştir.

65 Fatsa,2014,48.

66 Fatsa, 2015, 63,64. 


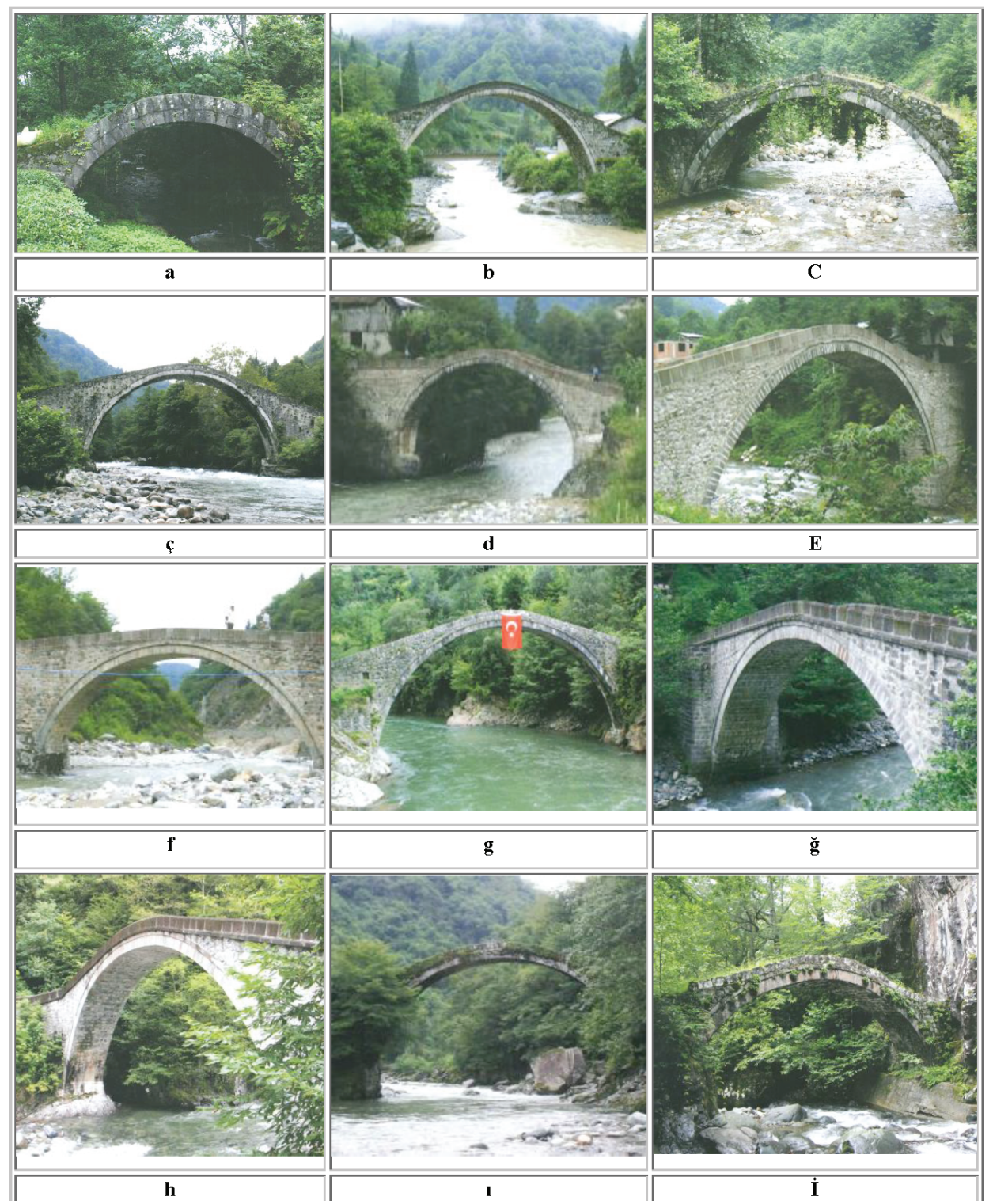

Tablo 1: Tek Açıklıklı, Tek Merkezli Rize Kemer Köprülerinden Örnekler.

[a. Köşklü Değirmen Köprüsü, İyidere (N40 59.787 E40 21.796) b. Kaptanpaşa -Yeşiltepe- Köprüsü, Çayeli (N40 58.025 E40 47.684) c. Erenler Köprüsü II, Hemşin-Pazar ç. Ortan Köprüsü, Çamlıhemşin (N41 00.431 E40 59.391) d. Aşağı Suçatı Köprüsü, Pazar (N41 05.853 E40 53.689) e. Yukarı Suçatı Köprüsü, Pazar (N41 06.018 E40 53.729) f. Büyük Taş Köprü, Hemşin (N41 04.273 E40 53.234) g. Köprüköy Köprüsü, Ardeşen (N41 07.399 E41 02.398) ğ. Çamlıhemşin Merkez Köprüsü, h. Mikron Köprüsü, Çamlıhemşin (N41 02.699 E41 01.491) 1. Seslikaya Köprüsü, Ardeşen (N41 08.900 E41 02.070) i. Tunca Köprüsü II, Ardeşen (N41 07.350 E41 07.419) (Ataman, 2015, 27’ den işlenerek). ] 


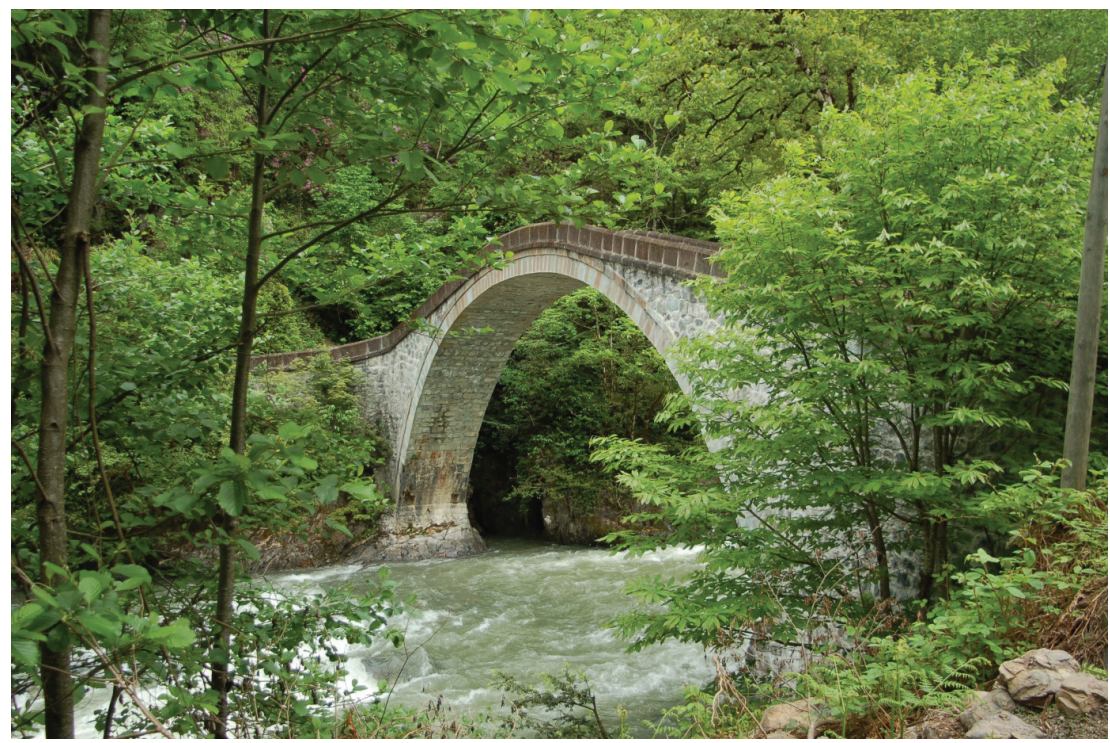

Fot. 3: Mikron Köprüsü.Çamlıhemşin, Rize. (2012, S. Başkan)

\section{Tek Açıklıklı Doğu Karadeniz Kemer Köprüleri}

\section{Tanımlama ve Tipoloji}

Bilinen tarihi boyunca mimarlık olgusu ile ilgili deneyim ve birikimleri açısından seçkin tür ve örneklere sahip Doğu Karadeniz, Anadolu'da en yoğun köprü yapım faaliyetinin icra edildiği bir bölgedir. Özellikle, Doğu Karadeniz halk yapı sanatı repertuvarı içinde önemle yer alan, bugüne gelen örnekleri 19. Yüzyılın ilk yarısı ile 20. Yüzyılın başlarında yapılmış olan tek açıklıklı taş kemer köprüler, özel ve önemli bir tipoloji oluştururlar. Özellikle, bu makalede, tarihlendirilmeleri konu edilen geç Osmanlı ve erken Cumhuriyet dönemine ait, Doğu Karadeniz vadilerinin tek açıklıklı taş kemer köprüleri, konum ve işlevleri yanı sıra estetik siluetleriyle de seçkin örneklerdir. Karadeniz coğrafyasının fethinin ardından bölgeye yerleşen öncü Türk toplulukları ve muhtemelen aynı toprakları paylaştıkları yerli komşuları belki birlikte, yaşadıkları dağlık ve ormanlık arazi yamaçlarında yaptıkları hayvancılık ve tarım faaliyetlerinin yarattığı sınırlı ekonomik değerle, vadiler boyunca yaşamlarını kolaylaştıracak, dereleri aşmalarını sağlayacak ilk tek açıklıklı taş kemer köprüleri yapmışlardır. Ancak sık yaşanan sel felaketleri sebebi ile bu köprüler sık sayılabilecek zaman aralıklarında yıkıldıklarından yeniden inşa edilmişlerdir. Bu yapılar bazen yıkılmasalar da yaşanan afetlerde ciddi şekillerde etkilenerek hasar görmüşlerdir. Bu devinim günümüze kadar sürmüş ve sürmektedir. Bu aşamada bugüne kadar tespit ve değerlendirmesini yaptığımız tek açıklıklı Doğu Karadeniz taş köprülerinde görülen hasarlar olarak; tempan duvarlarda 
meydana gelen boşluklar, derzlerin boşalması, köprü ayaklarında çökme ve oturma, köprü ayaklarının temel veya sömellerinde oyulmalar, tempan duvar yüzeylerindeki çatlaklar ve çökmeler, kemer karnı ve kemer yayında çatlaklar ve bölgesel göçmeler, tarihi strüktüre aşırı yükleme şeklinde muhdes ilaveler ve son olarak da ince yonu kaplama taşlarında erozyon ve kirlenme olduğu belirtilmedidir. Yapılan kötü restorasyonun da bu yapıların hasar görmesine veya daha kötüsü tahrip olmasında önemli bir etken olduğu bazı örneklerde görülmüştür. Örneğin, $40.28 \mathrm{~cm}$ uzunluğunda, 3.20 eninde gelişkin bir konstrüksüyon sistemine sahip Doğu Karadeniz köprülerinin seçkin bir örneği olan Rize Ambarlı köprüsü 2011 yılında Karayolları Genel Müdürlüğü’nce restorasyonunun tamamlanmasının üzerinden çok geçmeden 2019 yılı Haziran ayında yıkılmıştır.
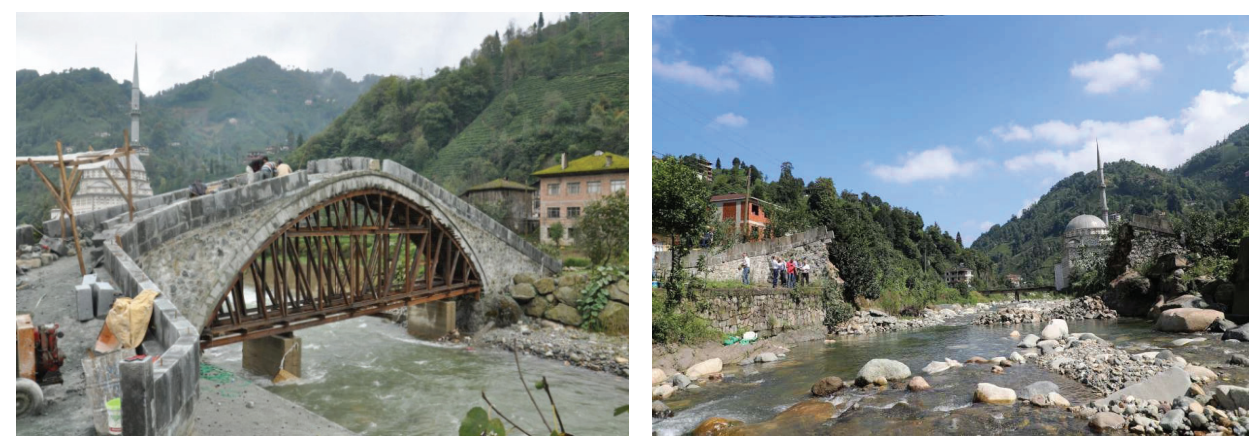

Fot. 4a - 4b: 2011 yılında restorasyonu yapılan ve 2019 y1lında yıkılan Rize Ambarlı Köprüsü. (Türkiye Kültür Portali, 2018) (Hürriyet, 2019)

Kemer geometrisinin şeklini belirlediği bu köprüler genellikle; geniş ve yüksek kemere doğru her iki yandan sert bir eğimle yükselen ya da köprü kemer ayaklarının oturduğu zeminle kemer yayı kotunun aynı ya da yakın olması sonucu tabliyenin düz veya hafif eğimli olduğu iki temel tipte yapılmışlardır. ${ }^{67}$ Köprü mimarlığının genel yapı sözlügüünü kullanan bu yapıların benzerleri Anadolu'nun pek çok bölgesinde görülmekle birlikte, Doğu Karadeniz vadilerinde bölgenin topoğrafyası, ekolojisi ve doğal ortamı nedeniyle çok farklı bir siluet arz ederler. Genel anlamda, bölgedeki yerel halk sanatını biçimlendiren temel faktörlerin belirleyiciliği köprü yapıları için de geçerlidir. Bölgenin yöresel mimarlığının biçim, işlev ve mekân organizasyonu mantığını belirleyen bu temel etkenler, bölgenin yaşamsal gerekliliklerinin sonucu ortaya çıkmıştır. Genellikle taş olan köprü malzemesi, teknik faydalar söz konusu olduğunda, başka tür malzemelerle ortak olarak da kullanılmıştır.

Tek açıklıklı kemer köprülerin yükseklikleri ve uzunlukları inşa edildikleri akarsu yatağının boyutlarına orantılı olarak değişiklik göstermektedir. Köprü ayakları

67 İlter, 1978, 27; Çulpan, 2002, 6. 
genellikle bir veya iki yönde de doğal kayalara oturtulmuştur. Köprülerin korkulukları da tabliyenin her iki yanında tek sıra kesme taş ile oluşturulmuştur. Köprülerin kemerleri düzenli kesme taş, duvarları ve köprü yolu ise düzenli moloz taştan yapılmıştır. Çoğunlukla yükseklikleri 2 ile 22 metre, uzunlukları 5 ile 57 metre arasında değişmekle birlikte ortalama yükseklikleri 5 metre, uzunlukları 25 metre civarındadır.

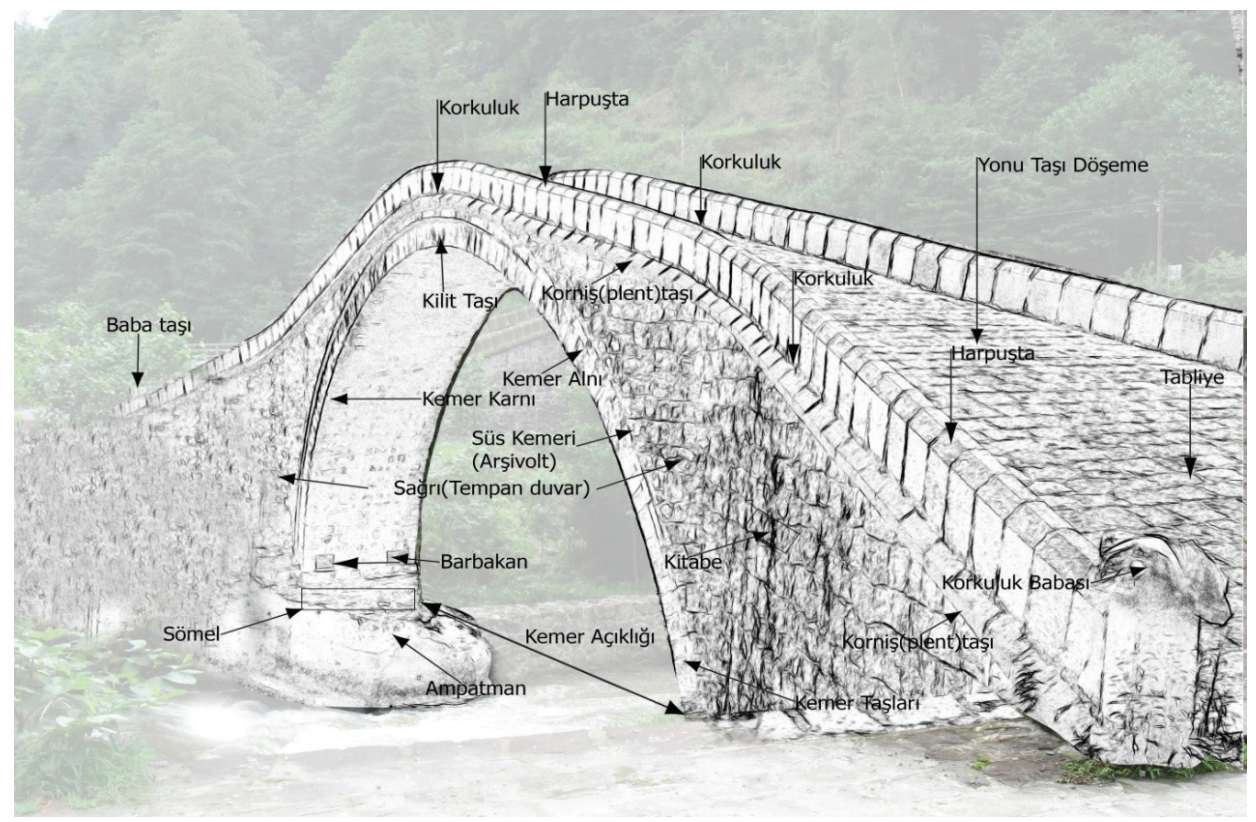

Şekil 3: Tek Açıklıklı Kemer Köprü Yapı Elemanları. Çifte Köprü, Arhavi, Artvin. (FotoSketch/ işleme: 2018, S. Başkan - Ö. Tavacıgil)

Trabzon Kültür Varlıklarını Koruma Bölge Kurulu Müdürlüğü kayıtlarına göre (Temmuz 2019); Rize'de 99, Gümüşhane'de 53, Trabzon'da 147, Giresun'da 64, Artvin'de 44 (Aralık 2015) adet köprü 1. Derece anıt eser, kültür varlığ 1 olarak tescil edilerek, yasal koruma altına alınmışır. Bölgede, kurumsal, bireysel veya TKVKBK Müdürlüğü elemanlarının yeni tespit ve tescil önerileri ile bu sayının arttığı görülmüştür. Bölgede henüz koruma altına alınmamış, değerlendirilmemiş çok sayıda benzer köprü olduğundan yukarıda verilen sayılar takip eden süreçte de $\operatorname{artacaktır}^{68}$.

68 2001-2017 yılları arasındaki ortak mesaimiz boyunca, maddi kültür mirasımızın tespit ve tescili için bölgedeki zorlu koşullara rağmen fedakârca çalışmalarına tanık olduğum Trabzon Kültür Varlıklarını Koruma Bölge Kurulu uzmanları ile kurul üyesi arkadaşlarıma ve özellikle mimar Serpil Yüksel'e katkıları için şükranlarımı sunarım. 


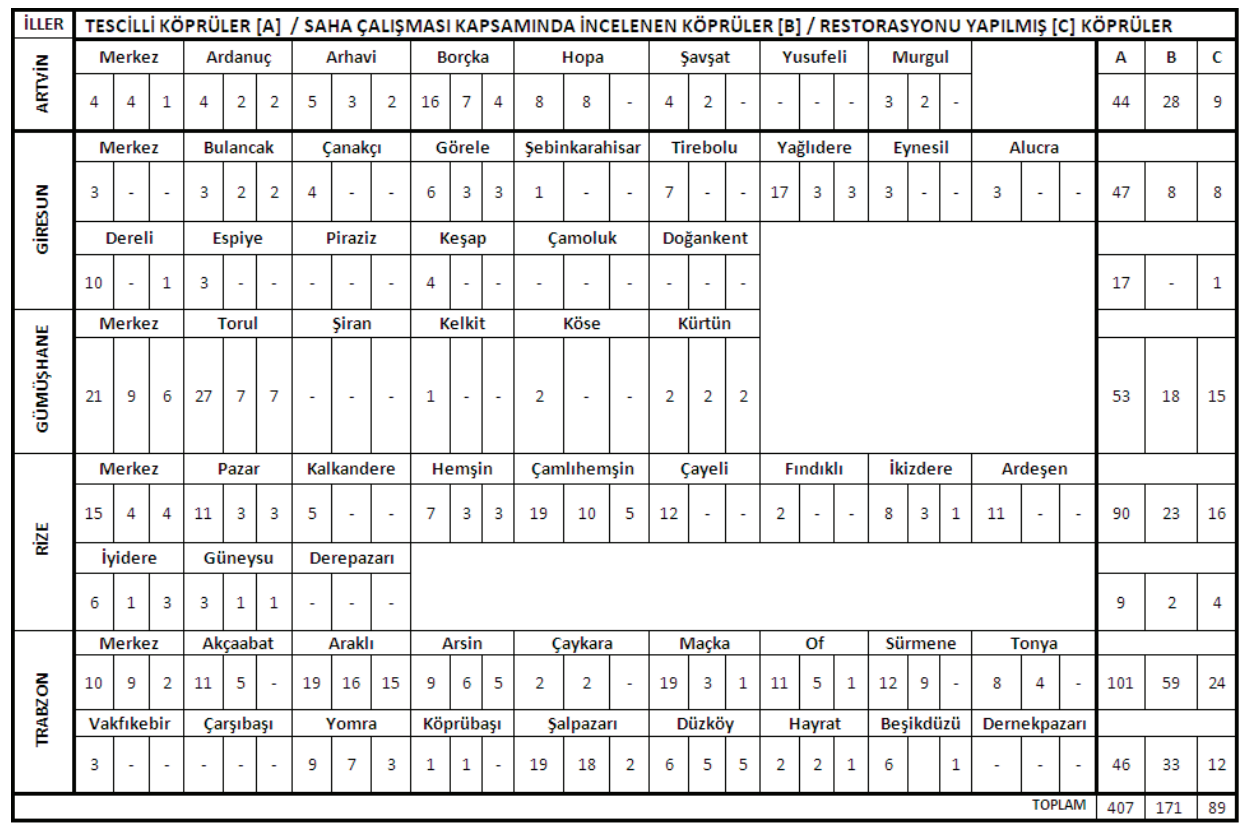

Tablo 2: Tescilli Tek Açıklıklı Doğu Karadeniz Kemer Köprüleri.[Artvin, Aralık 2015] (S.Başkan,Temmuz 2019)

\section{Tarihi Kaynaklar, Belgeler}

Artvin, Rize, Gümüşhane, Trabzon ve Giresun illerindeki tek açıklıklı köprüler, yollar ve bu ulaşım sistemi içindeki rolleri ile özellikle Giresun, Gümüşhane, Trabzon ve Rize ile civarındaki derbend ve zaviyeler ile bölgenin demografi ve iktisadi yapısı hakkında bilgiler veren, Tahrir Defterleri, Seriye Sicilleri, Vakfiye ve Salnâmeler gibi bazı Osmanlı devlet kayıt ve yazışmalarından oluşan arşiv belgelerinde çok önemli bilgilere ulaşılmıştır. Özellikle, H. Bostancı,' M. D. Tosun ve M. Fatsa'nın yayınladıkları tahrir defterleri ${ }^{69}$ içinde Başbakanlık Osmanlı Arşivindeki; 13 numaralı "Vilayet-i Bayramlu me'a iskefsie ve Milas" adl 1455 tarihli, 387 numaralı "Muhasebe-i Vilayet-i Karaman ve Rum Defteri (937/1530)-II" adl1 1530 tarihli, 299 numaralı tarihli "Karahisar-l Sarki Avartzhaneleri Tahrir Defteri" adl1 1642 ve 478, 482, 557 ve numaralı 1455, 1485 ve 1520 tarihli tahrir defterlerinde Doğu Karadeniz dağlarının güneyinden Doğu Anadolu'ya oradan da İran'a ulaşan transit yolun bölge içindeki ara yol bağlantıları, bu

69 Osmanlı döneminde yapılan nüfus ve arazi tespitlerinin kaydına yazma, yazılma anlamına gelen tahrir, bu kayıtların tutulduğu defterlere de Tahrir veya Tapu Tahrir Defterleri denilirdi. Tapu tahrir defterleri vilâyet ve sancaklardan toplanan vergilerin, vergi mükelleflerinin ve Timar, Zeamet ve Has gibi idari ve askeri idarelerin gelir kaynaklarının kaydedildiği defterler olduğu için içlerindeki kayıtlarla tarihe 1şık tutarlar. 
yollar üzerindeki köprüler ile bu sistemin idari, askeri ve ekonomik durumundan bahisle önemli bilgiler yer almaktadır. Çalışma kaynakları içinde bir başka önemli arşiv belgeleri de, Mahkeme sicilleri, kadı sicilleri veya kadı defterleri de denilen şer>iyye sicilleridir. ${ }^{70}$ Şer'iyye sicillerinden, dönemine ilişkin halkın; tüm sosyal, kültürel, siyasi yaşantısı, yaşadıkları ortam, devletle ilişkileri gibi pek çok konuyu öğrenmek mümkündür. Mahallî mahkemelerde kronolojik sıra ile tutulan ve diğer konularla birlikte pek çok kanunun kaydedildiği bu defterlerdeki kayıtlarda bazı köprülerin adlarında rastlanan aile adlarına rastlanmaktadır. Bölgede özellikle Rize, Giresun ve Trabzon ${ }^{71}$, Gümüşhane ${ }^{72}$ şer>iyye sicilleri üzerinde tamamlanan çalışmalar olduğu gibi bu konuda çalışmalarını sürdüren araştırmacılar da mevcuttur. Osmanlı tarihine ilişkin en önemli kaynaklar arasında yer alan döneminin ekonomik, sosyal, dinî, mimarî, kültürel ve sosyal faaliyetlerinin yansıdığı vakfiyeler de bölge tarihine ilişkin emsalsiz bilgiler verirler. H. Bostancı'nın çalışmasında ${ }^{73}$ ulaşılan Giresun Dereli ilçesine bağlı Konuklu köyündeki Seyh Mahmut, merkez Tekke köyünde Yakup Halife, Piraziz Gökçeali'de Seyh idris, Yağlıdere'de Hacı Abdullah Halife ve Kızıltas köyünde Hacı İlyas zaviyelerine ait vakfiyeler örnek olarak belirtilebilir. 19. yüzyıl ortalarından başlayarak yaklaşık yüzyıl boyunca hem Osmanlı hem de Cumhuriyet dönemlerinde önemli olayları özetleyen ve ait olduğu yılın kurumsal, idari, sosyal, kültürel olay ve bilgilerinin verildiği salnâmeler ${ }^{74}$ de önemli tarih kaynakları arasındadır. Doğu Karadeniz bölgesinde yaşanan önemli sosyal olaylar, sel felaketleri ve bayındırlık faaliyetleri bu eserlere yansımıştır.

70 Osmanlı devletinin merkez ile taşra teşkilatı arasındaki yazışmaları, halkın şikâyet ve dileklerini içeren arzuhalleri; ferman ve hükümleri, en önemlisi de bulunduğu yerde görülüp karara bağlanmış ilâmları (mahkeme kararları) içeren Şer'iye Sicilleri, özellikle Osmanlı idari teşkilatının son dönemlerinin araştırılmasında, hukuk tarihi, iktisat tarih, idari teşkilat, sosyal hayat ve askeri yapı konularında temel kaynaklardandır. Osmanlı şer'iyye sicilleri 15. yüzyıl ortaları ile 20. yüzyıl aralığına tarihlenirler.

71 Trabzon'a ait ilk şer'iyye sicili 1555 yılına aittir. Prof. Ahmet Akgündüz'ün hazırladığ Şer'iyye Sicilleri Toplu Kataloğu'nda Trabzon'a ait 296 defter yer alır. Hicri 963 ile 966 tarihleri arasındaki kayıtları içeren ilk sicilin numarası 1815'tir. Bundan sonra kronolojik boşluklar içerse de Trabzon Şer'iyye Sicilleri imparatorluğun yıkılışına kadar düzenli bir şekilde tutulmuştur. 2111 numaralı son sicil ise Hicrî 1226-1229 tarihleri arasını kapsamaktadır. Bu defterlerin orjinalleri Ankara'da Milli Kütüphane'de olup fotokopileri Trabzon İl Halk Kütüphanesi ve İsmail Hakkı Berkmen Tarih Kütüphanesi’ndedir. Açık, 2014; Öksüz 2004.

72 Demir-Dönder, 2017, 160-171.

73 Bostanc1, 2007, 6,20,78.

74 Farsça yıl demek olan "Sal" ile mektup anlamına gelen "nâme" kelimelerinden oluşan Salnâme kelimesi, eski yıllardaki önemli olayları özetleyen ve ait olduğu yılın kurumsal, idari, sosyal, kültürel olay ve bilgilerinin verildiği geç dönem Osmanlı yazılı eserleridir. İlk salnâme 1263 (1847) yılında Mustafa Reşid Paşa'nın öncülüğünde çıkarılmıştır. 


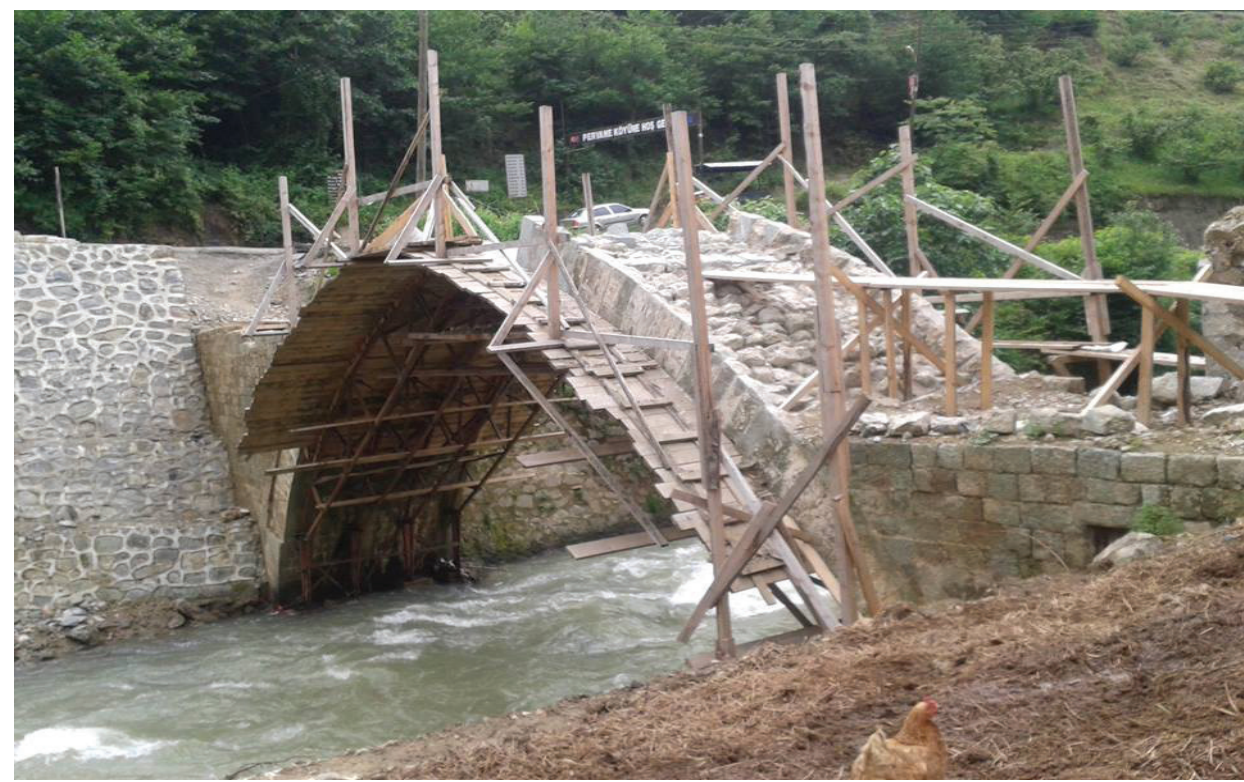

Fot. 5: Pervane Köyü Köprüsü Restorasyonu. Arakl1, Trabzon (TKVKBK, 2015).

\section{Tarihlendirme}

Tek Açıklıklı Doğu Karadeniz kemer köprülerinin ne zaman ve kimler tarafından yaptırıldıkları konusu önemli bir sorundur. Kitabesi ve hakkında arşiv kaydı olmayan bölgedeki tek açıklıklı taş kemer köprülerin büyük kısmının yörede yaşayan kişilere atıf yapılarak, varsayıma dayalı tarihlendirilmesi, zamanla da bu bilgilerin benimsenmesi, yanıltıcı bir saha tarihi oluşmasına sebep olmuştur. Köprüleri kültür varlığı olarak tescil eden ve koruma kararını alan koruma kurulundaki tescil fişlerinde dahi bu tür varsayıma dayalı tarihlendirme ve anlatımlara yer verilmesi ise bu sorunu resmileştirmiştir ${ }^{75} . \mathrm{Bu}$

75 Bu noktada, Kültür ve Turizm Bakanlığı'’nın, koruma kurulu arşivlerinde karşılaşılan sorunları aşmak için belgelerin digital ortama aktarılarak digital arşiv oluşturma projesi henüz uygulamada pratik çözümler getirmekten uzaktır. İçerikleri ve bilgilerinin yenilenmesi, güncellenmesi zorunlu olan 1951-1983 yılları arasındaki "Gayrimenkul Eski Eserler ve Anıtlar Yüksek Kurulu" (GEEAYK) tescil fişlerinin digital ortama aktarılmış olmasının pratikte bir faydası yoktur. 1951-1983 yılları arasında koruma altına alınan eserlere ilişkin kayıtlardaki; soluk kötü fotoğraflar, ne anlattığı zor anlaşılan veya hiç olmayan betimlemeler, eserin bulunduğu yeri tarif etmeyen veya olmayan 'bulunduğu yer' 'tespitleri' ile, bu eski anıt fişleri, söz konusu eserler hakkında bilgi vermekten uzaktır. Aynı vadi üzerindeki bir dereyi aşan iki veya daha fazla sayıda köprü için hazırlanan tescil fişlerine bakarak; örneğin Rize/Çamlıhemşin'deki Köprü 1 ile yine Çamlıhemşin Topluca Köyü Masellevat Mezrası'nda, Trabzon Kültür Varlıklarını Koruma Bölge Kurulu'nun (TKVKBK) 23/12/2005-518 gün ve sayılı Kararı ile tescil edilmiş Köprü 2, veya 
şekildeki somut olmayan, yanıltıcı bilgileri tartışmadan kullanan, çeşitli basın organları ve diğer yayınlar bu konudaki sorunu içinden çıkılmaz bir şekilde ağırlaştırmış ve büyütmüştür. Bir noktadan sonra bu yanlış ve yanıltıcı bilgiler, söz konusu yapıları gerçek tarihlerinden koparmış ve bu maddi kültür mirasının özgün mimari özellik ve niteliğinin de bozulmasına yol açmıştır. Bölgedeki tek açıklıklı taş kemer köprülerin restorasyonu için hazırlanan bir kısım sanat tarihi ve restitüsyon raporunda da bu tür varsayıma dayalı tutarsız ve yanlış ifadelere yer verilerek, yapıların yapıldığı zamandaki özgün halini yansıtmayan restitüsyon önerileri yapılmıştır. Fazla olmamakla birlikte, bu konuda çalışma yapan araştırmacılar, benzer yapı ve malzeme özellikleri nedeniyle stil kritiği yöntemiyle tarihlendirme yapamadıklarından bu konuda daha çok yerel, sözlü kaynaklara bağlı kalmışlardır ${ }^{76}$.

Eski zamanlardan bu yana varlığını koruyarak günümüze gelen veya yıllar içinde sellerle yıkılan, tekrar yapılan veya onarılan Giresun, Trabzon, Rize, Gümüşhane ve Artvin illerindeki tek açıklıklı kemer köprüleri konu alan bu çalışma ilk olarak Üniversite Bilimsel Araştırma projesi olarak 2009 yılında başlamıştır. 2011 yılında biten bütçe ile beraber proje tamamlanmakla birlikte konuya ilişkin araştırma ve çalışmalar 2017 yılına kadar sürdürülmüştür. Bu çalışmada ilk ve öncelikli amaç bölgedeki önemli taşınmaz kültür mirası içinde yer alan bu yapıların somut kaynaklara dayalı bir mimarlık tarihi yazımı olmuştur. Bugüne kadar yerel hikayeler içine serpiştirilmiş anlatımlarla anılan, büyük kısmı günümüze ulaşmamış olmakla birlikte, Rize il merkezinde bir kavşak asfaltı altında kalan H.1305/M.1887-88 tarihli Çıtağın Köprüsü veya çok yoğun bitki örtüsü altında kalarak unutulmuş H.1320 / M.1902-3 tarihli Hemşin Deresi üzerindeki Suçatı III köprüsü gibi bir çok köprünün kitabesine ulaşılarak veya resmi devlet yazışmalarına yansıyan tarihi vakalar içindeki yerleriyle tarihlendirmeleri yapılmıştır. ${ }^{77}$ Trabzon Kültür

aynı mezrada TKVKB Kurulunun 23/12/2005-518 gün ve sayılı Kararı ile tescil edilmiş Köprü 3'ü Ya da Giresun Çanakçı İlçesi Karabörk Beldesi'nde TKVKB Kurulunun 12.09.2008-1762 gün ve sayılı Kararı ile tescil edilmiş Kemer Köprü ile hemen yakınındaki TKVKB Kurulunun 12.09.2008-1762 gün ve sayılı kararı ile tescil edilmiş köprü hakkında fikir yürütmek ya da birbirinden ayırmak mümkün değildir. Zaten çoğunda fotoğraf ve tanımlama dahi olmayan, eserlerin tarihlendirilmesi ise fişi hazırlayanın hayal gücüyle sınırlı ifadelerden oluşan bu tescil kayıtlarının arşiv bilgisi değeri olmadığından acilen güncellenmeleri gerekir.

76 Bk. Altınsapan,2001.

77 Bk. Cumhurbaşkanlığı Devlet Arşivleri Başkanlığı (Eski Başbakanlık Osmanlı Arşivi ) uhdesinde bulunan; [ŞD (Arşiv Fon Kodu). Dosya No: 1782 B, Gömlek No: 8, Tarihi: 1288 B 08/23 Eylül 1871; Y..PRK.UM.. Dosya No: 4, Gömlek No:2, Tarihi: 14 (Za) Zilkade 1297 /18 Ekim 1880; Y..PRK.UM..Dosya No: 1, Gömlek No: 104, Belge Tarihi: 13 Şevval 1297/17 Eylül 1880; DH. MKT, 1599/44. 27 Şubat 1889; Y.PRK.AZJ 41/62, 2 Şaban 1308/13 Mart 1891; DH.MKT. 290/4. 25 Eylül 1894; Y.PRK.ZB,17/28, 9 Ramazan 1313/23 Şubat 1896; DH.MKT. Dosya No: 2175, Gömlek No: 7, Tarihi : 24 Şevval 1316/7 Mart 1899; DH.MKT. Dosya No: 2199, Gömlek No: 107, olan, 28 Z 1316/ 9 Mayıs 1899; DH.MUİ. Dosya No: 95, Gömlek No: 49, Tarihi: 1328 Ca 21-1910/1911; DH.EUM,5Şb,17/27, 21 Zilkade 1333/30 Eylül 1915; DH.EUM.5.ŞB. 17/41, 24 Zilkade 1333/3 Ekim 1915; DH. UMVM,139/62. 6 Haziran 1916; 
Varlıklarını Koruma Bölge Kurulu sorumluluk sahası olan bölgede tescil edilen 407 köprü içinden restorasyonu yapılmış 89 köprü dahil 171 tanesi bu kapsamda incelenmiştir ${ }^{78}$.

Metrekareye düşen yağış ortalaması Anadolu ortalamasının dört, beş katı olan bölge yağış rejiminin yol açtığı doğal afetler ve tahribatları 19. Yüzyıl Osmanlı devlet yazışmalarına yansımıştır. Trabzon ve Rize ile ilgili bazı rapor ve belgelerde sık sık sel felaketleri, yol, köprü tamir ve inşaatlarından söz edilmiştir. Başbakanlık Osmanlı Arşivi’nde bulunan Rize sancağına ilişkin 2 Şaban 1308/13 Mart 1891 tarihli Taşlıdere üzerinde bir köprü yaptırılmasına izin verilmesi konusunda Padişah II. Abdülhamid'e yazılan yazılan dilekçe ${ }^{79}$ ile 9 Ramazan 1313/23 Şubat 1896 tarihli İkizdere Nahiyesinde ortaköy ile Başköy'de yoğun karın sebep olduğu çı̆̆ felaketi sonrası çok sayıda can kaybı ile çeşitli binaların ve bu arada bir köprünün de yıkıldığını Zaptiye Nezaretine bildiren telgraf $^{80}$ erken örnekler arasındadır.

H.1276/M1859 yılına ait bir başka belgede, Rize ve Trabzon'da tahrip olan köprü ve yolların tamir ve inşa edilmeleri konu edilir ${ }^{81}$. Özellikle, Kurtuluş Savaşı yıllarında yerel kamu otoritelerinin köprü yapım faaliyetlerinden söz eden eski arşiv belgeleri son derece çarpıcıdır. 1919 ve 1920 yıllarında, Rus işgalinin olumsuz etkilerinin ve gayrimüslim isyancı çetelerin anarşi ve terör eylemlerinin sürdüğü Doğu Karadeniz illerindeki kamu kurumları, İstanbul'daki merkezi yönetimin plan ve talimatlarıyla seller nedeniyle yıkılan ve hasar gören köprülerin inşa ve tamiri işini yürütebilmişlerdir ${ }^{82}$. "Başbakanlık Osmanlı arşivinde sözü edilen bir başka örnek de Trabzon'un Tonya ilçesi Kozluca köyünde 1890'll yıllardaki bir sel felaketinde yıkılan köprünün onarılmasına ilişkin kayıttır ${ }^{83}$.

Başbakanlık Osmanlı Arşivi belgeleri içinde iki örnek de Giresun köprülerine ilişkindir.1880 tarihli bir belgede ${ }^{84}$ Giresun Şebinkarahisar (Karahisar-i Şarki) ilçesinde bulunan Mercimek, Avutmuş, Hacı Beğ, Hasan Ağa ve İmanlı Köprülerinin tamiri ile “iane-i me'murin ve ahali ile inşa kılınan” Biroğul Köprüsünden söz edilir. ${ }^{85}$ Yakın tarihli bir başka Osmanlı kaydında da Giresun ili Alucra ilçesine bağlı nahiyelerden olan Mindeval (Çamoluk) bölgesindeki Teşdik ve Avarak köylerinde bulunan köprülerin tamiri ve inşası konu edilmiştir. ${ }^{86}$

DH.UMVM,73/14-19, 3 Cemazeyilevvel 1338/24 Ocak 1920; BCA. 30. 10. 0. 0. 117.818. 29.

5 Temmuz 1929] belgeler.

78 Bk. Tablo 2.

79 BOA, Y.PRK.AZJ 41/62, 2 Şaban 1308/13 Mart 1891.

80 BOA, Y.PRK.ZB, 17/28, 9 Ramazan 1313/23 Şubat 1896

81 Safi, 2019, "Köprüler Yaptırdım.."

82 Safi, 2019, "Köprüler Yaptırdım.."

83 Aslan, 2019, "Trabzon ili Tonya ve.."

84 BOA, 4, Y.PRK.UM, 2, H. 14 Zilkade 1297 / M.18 Ekim 1880.

85 Tosun, 2019, "1880 tarihli.."

86 Tosun, 2019, “1880 tarihli..” 

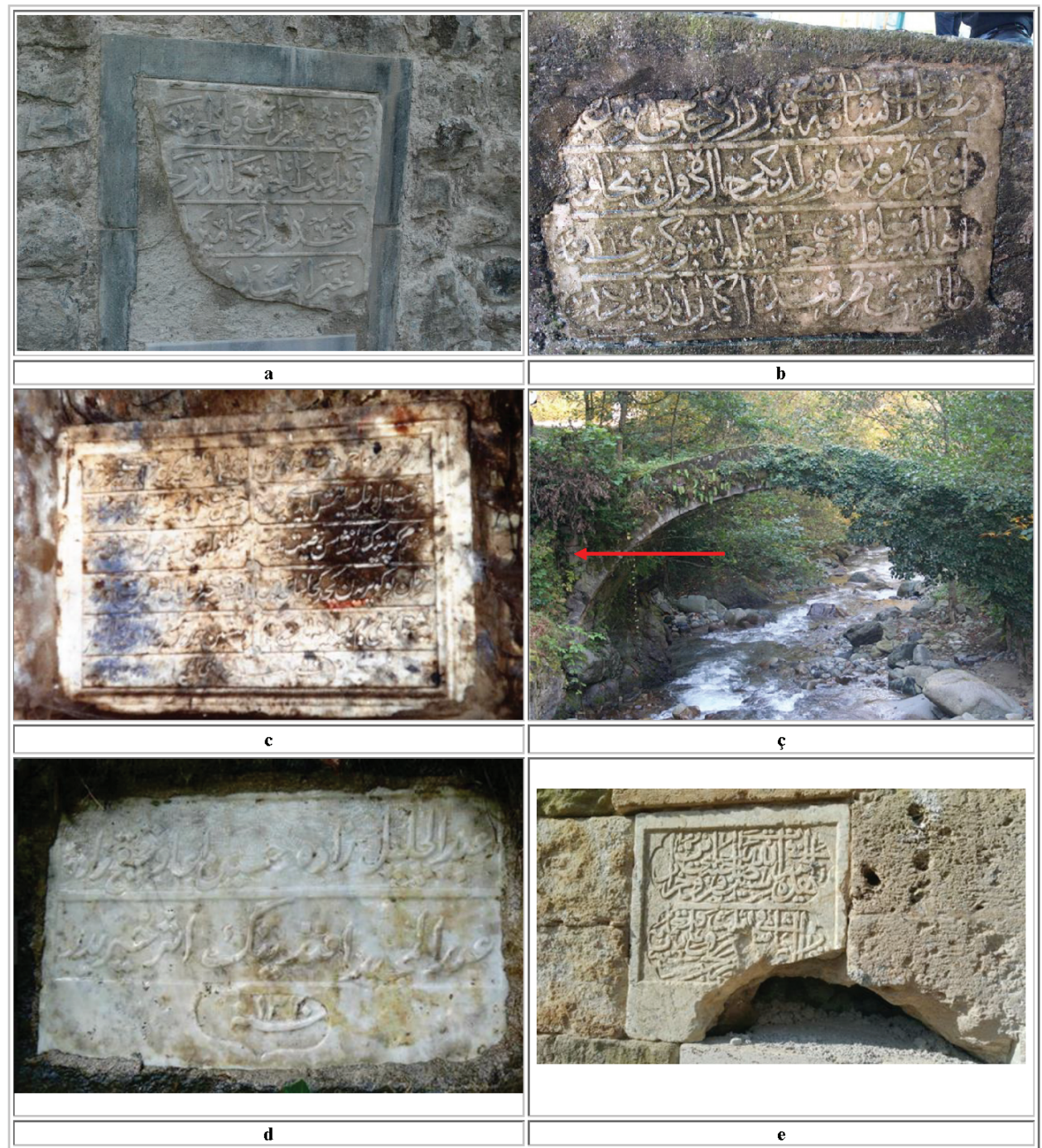

Tablo 3:

a. Giresun Yağlıdere Ümit Bükü Köyü yakınındaki Ağa köprüsü kitâbesi, H.1232/M.1816/17 b. Trabzon Akçaabat ilçesi Derecik Beldesi Oğulkaya Köyü’ndeki Oğulkaya Köprüsü, H. 1314/M.1896 c. Rize Merkez Kale Mahallesindeki Çıtağın Köprüsü Kitabesi, H. 1305 / M.1887-88 (TKVKBK, 2017) ç. Rize ili Çamlıhemşin ilçesi Güroluk (Eski Hala/Livik Çakeşli) Köyü Köprüsü kitabesi, (TKVKBK, 2017) H.1212/M.1797-98 d. Rize ili Pazar ilçesi Suçatı III köprüsü, H.1320 / M.1902-3 e. Gümüşhane merkezi Harşit/Karakol Köprüsü kitabesi, H. Recep-983/ M. Ekim-1575. (2019, S. Başkan) 
I. Dünya savaşı sırasında Rus savaş gemilerinin Türk kıyılarına karşı yaptıkları askeri hareketlilikleri ve verdikleri hasarı kaydeden yerel yöneticilerin İstanbul'daki ilgili kurumlara gönderdikleri raporlar içinde köprü tahribatına ilişkin bilgiler de vardır. 21 Zilkade 1333/30 Eylül 1915 tarihli bir belgede ${ }^{87}$, Rize Fındıklı'da Tahiroğlu Deresi üzerinde bir köprünün Rus torpidobotu ateşiyle yıkıldığ1, 24 Zilkade 1333/3 Ekim 1915 tarihli bir başka belgede de Trabzon Valisi Cemal Azmi'nin Dahiliye Nezaretine gönderdiği Telgrafta, Trabzon'u bombalayan düşman torpidosunun verdiği zararı ve bu arada sahili tarayarak Akçabat Pulathane'de bir köprüyü tahrip ettiğini bildirmektedir. ${ }^{88}$

Büyük kısmının arşiv kayıtlarından yapım yılı, bani, mimari özellikler gibi birçok ayrıntı bağlamında bilgi edinilmesi mümkün olmayan bölgedeki tek açıklıklı taş kemer köprülerin ne zaman ve kimler tarafından yaptırıldıkları konusu yukarıda da belirtildiği gibi bu yapıların önemli sorunlarından birisidir. Koruma Kurulunca kayıt altına alınmış olsalar dahi bu yapıların tarihlendirilmelerindeki problemler devam etmiştir. Tek açıklıklı taş kemer köprüleri kimlerin ne zaman yaptırdığı bilgisini veren kitabeye sahip örneğin az olması, üstelik var olan köprü kitabelerinin de bu yapılara ait olmama ve devşirme olma ihtimalleri bu konudaki sorunu büyüterek sürdürmüştür. Bu sebeple yıllara yayılan özenli saha çalışması sonunda Giresun'da 3, Rize'de 18 ve Trabzon'da 9 köprünün kitabeleriyle kesin tarihlendirmesi yapılmıştır ${ }^{89}$. Kitabeli bu köprüler içinde 19. Yüzyıla ait olanlar H.1244/M.1828 - H. 1314/M.1896 tarihleri arasında, 20. Yüzyıla ait olanlar ise ilk yarım yüzyıl içinde yapılmışlardır.

\section{Sonuç}

Tarihin her döneminde üç eski kıta arasında bir geçit olan Anadolu'da, çok eski çağlardan beri bu coğrafyada yaşayan kültürler tarafından ticari ve askeri amaçla yollar ve köprüler yapılmıştır. 11. yüzyılda Anadolu'ya gelen Türkler de bu tarihi yolları imar ederek, ticareti geliştirmişlerdir. Ortaçağda Anadolu'daki ticaret yolları çok iyi organize olmuş hanlar/kervansaraylar düzeni ile korunmuş ve ekonomik yaşamın güvenli sürdürülebilirliği sağlanmıştır. Anadolu'nun fethi sırasında yararlılıklar göstermiş kolonizatör dervişler ve ailelerinin yerleştikleri bölgede yaptıkları tekke, türbe ve zâviye, cami, medrese gibi yapılar zamanla tasavvufî bir niteliğe bürünüp mistik ve ruhani kimlik kazanmışlardır. Daha sonra köprücü ve derbend olarak görevlendirilecek bu zâviyeler daha çok kapalı bir havza olan Karadeniz'in sahil kesimini Anadolu'nun diğer bölgelerine bağlayan tarihi geçitler ve yollar üzerinde yer almıştır.

Geç dönemlere kadar, Yeşilırmak ve Çoruh nehri arasındaki Doğu Karadeniz vadilerini birbirine bağlayan devamlı bir karayolu bulunmadığından, bölgedeki yolların, köprülerin bakım onarım ve güvenliğini sağlayan zâviye ve derbendler, nadiren doğu-batı yönündeki Karadeniz vadilerinde görülürken, daha çok güneye, Anadolu içlerine açılan

87 BOA, DH.EUM,5Şb,17/27, 21 Zilkade 1333/30 Eylül 1915.

88 Demircioğlu,2008, 298,299.

89 Başkan, 2009. 70-74. 
vadi ağızları ve içlerinde konumlandırılmışlardır. Doğu-batı yönünde üç ana güzergâhtan oluşan transit Anadolu ticaret yollarından, Kuzey Anadolu transit ticaret yolu ile Karadeniz şehirleri ve limanlarıyla bağlantılı ara yollar üzerindeki menziller boyunca günümüze ulaşmış küçüklü büyüklü çok sayıda köprü bulunur.

Tek açıklıklı Doğu Karadeniz kemer köprüleri, üzerinde yer aldıkları akarsu üzerinde her iki yandan yükselerek oluşan çoğunlukla yarı dairesel ya da hafif sivri kemerli bir şekle sahiptirler. Farklı coğrafyalardaki çeşitli kültürlerin mimarlık geleneklerinde de kullanılmış olan bu kemer geometrisinin temel özelliği dar su geçitlerini sel veya taşkınlardan etkilenmeden geçmek esasına dayanır. Doğu Karadeniz'in dar vadilerindeki akarsuları geçen bu tip köprüler yanı sıra daha geniş yatağa sahip olan dereler üzerinde birden fazla kemerli köprüler de vardır. Ancak Karadeniz'in yüksek debili derelerinde yapılan bu tip köprüler de, Rize Pazar köprüsünde olduğu gibi, yüksek orta kemer ve bu kemere ulaşmayı sağlayan yan kemerler şeklinde inşa edilmişlerdir. Hemen hemen tek açıklıklı köprülerin büyük kısmı her iki yönde de doğal kaya zemine oturtulmuştur. Bir kısmı günümüze gelememiş olmakla birlikte bu köprülerin temel tasarımında köprü yolunun her iki kenarında korkuluk yer alır. Tek açıklıklı Doğu Karadeniz köprüleri düzgün kesme ve moloz taş ile yapılmışlardır. Karadenizli halk yapı sanatçılarının bu konudaki tercihi çoğunlukla andezit ve bazalt gibi sert taşlar olmakla birlikte yerine göre kalker esaslı kolay işlenebilen taşlar da olmuştur.

Doğu Karadeniz kemer köprüleri, bölgedeki maddi kültür varlıkları arasında en önemli türlerden birisidir. Bu yapılar bölgedeki Türk mimarlık yaratıcılığının en seçkin örneklerindendir. Bu yapılar bölgedeki son dönem Osmanlı mimari eserleri olmaları bakımından da önemlidir. Geçmişi bugüne bağlayan ve tarihi varlıklarımızdan birisi olan bu yapılar özenle korunarak gelecek kuşaklara aktarılacak tarihi bir mirastır. Son yıllarda farklı nedenlerle tarihsel mirasının yok oluş sürecini yaşayan Doğu Karadeniz'de son zamanlarda gelişme adına yaşanan bazı uygulamalar da bu tarihi yapıların yok olmasının önünü açmıştır.

Sözün burasında, çok önemli olduğu tartışılmaz bir misyon üstlenmiş olan Karayolları Genel Müdürlüğü'nün kuruluş kanunu ile üstlendiği tarihi köprülerin koruma, onarım ve restorasyon çabalarını taktir etmemek mümkün değil. Ancak, Giresun, Trabzon, Rize, Artvin ve Gümüşhane illerindeki alan çalışması sırasında köprü yapısının tarihi yapısının tümüyle bozulduğu, özgün bir yanı kalmayan çok sayıdaki köprü de tespit edilmiştir. Zaten asrı aşan ömrüyle günümüze ulaşan bu yapılardan restorasyonu başarısız olanlar -Rize Ambarlı köprüsü örneğinde olduğu gibi- kısa bir süre sonra yıkılmaktadır. Karadeniz insanının mimarlık yaratıcılığının seçkin ürünleri olan bu köprüler için tarih boyunca olduğu gibi en önemli tehlike halâ afet şeklindeki seller olmakla birlikte son yıllarda varlığını tehdit eden başka unsurlar da ortaya çıkmıştır. Flora ve faunasıyla binlerce çeşit endemik bitki türünü barındıran, vadilerine, derelerine sahip çıkmaya çalışmakla yerel halkın önüne geçemediği bu tehlike; bu eşi bulunmaz doğayı ve nesillerce insan emeğini sular altında bırakan barajlar, HES'lerdir. Bu coğrafyadaki nesillerce insan 
emeği sular altında kalmaktadır. Örneğin Çoruh havzası projesi tamamlanıp tüm barajlar yapıldığında, Artvin ilinin 1/5'i yani Akdeniz iklimi hüküm süren Çoruh vadileri, bağlıklar, doğal, vahşi hayvan barınak ve göç yolları, ata mezarları, geleneksel Anadolu Türk evleri, camiler, kaleler, köprüler su altında kalacaktır. 19. yüzyıldan miras tek açıklıklı Artvin köprülerinin yarısından çoğu tamamlanan Muratlı, Borçka, Deriner ve Artvin barajları altında kalmıştır. Bu durum telafisi mümkün olmayan büyük bir kayıptır. Tüm Anadolu'da olduğu gibi Doğu Karadeniz'de de tarihi ve kültürel değerlerin sürdürülebilirliği önceliği, bugünün kuşaklarına ekonomik beklentilerin çok ötesine geçen sosyal, siyasal, kültürel ve acil bir sorumluluk yüklemektedir. Çünkü, ekonomik bir değer olarak barajlar ve HES'ler ile tarihi çevre ve maddi kültür varlıklarının korunmasına ilişkin ortaya çıkan paradoksun bugünkü tercih ve çözümü gelecek kuşaklara yarını olmayan bir gelecek sunarak bu topraklardaki bin yıllık tarihsel hafızayı silerek yok edecektir. ${ }^{90}$

90 Başkan, 2009. 73,74. 


\section{KAYNAKÇA}

Altınsapan, E. (2001). Tek Kemer Gözlü Rize Köprüleri, Anadolu Üniversitesi Edebiyat Fakültesi Yayını, Eskişehir.

Arslan, E. (2017). Trabzon İli Tonya ve Beşikdüzü İlçeleinde Yüzey Araştırmalarına Dayalı Yerel Tarih Araştırmalarının Genel Tarih Anlayışına Yadsınamaz Katkısı ve Düşünceler. http://www.enverarslan.com/ bildiri/ (Erişim:Temmuz 2019)

Ataman, M, (2015). Rize İli Çamlıhemşin İlçesi Hala/Kale Köyü Köprüsü Restorasyon Tadilat Raporu (Sanat Tarihi ve Teknik Rapor) Karayolları Genel Müdürlüğü 10. Bölge Müdürlüğü. (Trabzon Kültür Varlıklarını Koruma Bölge Kurulu Arşivi) Trabzon.

Barkan, Ö. L. (1942). Osmanlı İmparatorluğu'nda Bir İskân ve Kolonizasyon Metodu Olarak Vakıflar ve Temlikler, I- İstilâ Devirlerinin Kolonizatör Türk Dervişleri ve Zâviyeler, Vakıflar Dergisi S. 2, s., 279-386.

Başkan, S. (2011), Tek Açıklıklı Doğu Karadeniz Kemer Köprüleri / Single Span Eastern Black Sea Humpback Bridges. Gazi Üniversitesi Rektörlügü Bilimsel Araştırma Projeleri. 05/2009-42. Ankara.

Başkan, S. (2012). Semerkand Şah-1 Zinde Yapıları. Vakıflar Dergisi, Başbakanlık Vakıflar Genel Müdürlüğü Yayını S.37, Haziran. Ankara s.,131166.

BOA, Arşiv Fon Kodu : Y..PRK.UM.. Dosya No: 1, Gömlek No: 104, Belge Tarihi: 13 Şevval 1297/17 Eylül 1880.

BOA, Arşiv Fon Kodu: DH.MKT. Dosya No: 2175, Gömlek No: 7, Tarihi : 24 Şevval 1316/7 Mart 1899.

BOA, Arşiv Fon Kodu: DH.MKT. Dosya No: 2199, Gömlek No: 107, olan, 28 Z 1316/ 9 May1s 1899.

BOA, Arşiv Fon Kodu: Y..PRK.UM.. Dosya No: 4, Gömlek No:2, Tarihi: 14 (Za) Zilkade 1297 /18 Ekim 1880.

BOA, Dosya No:03/C - H.1332 / M.1916.

BOA, Fon Kodu: BCA. 30. 10. 0. 0. 117.818. 29. 5 Temmuz 1929.

BOA, Fon Kodu: DH. MKT, 1599/44. 27 Şubat 1889.

BOA, Fon Kodu: DH. UMVM,139/62. 6 Haziran 1916.

BOA, Fon Kodu: DH.EUM,5Şb,17/27, 21 Zilkade 1333/30 Eylül 1915.

BOA, Fon Kodu: DH.EUM.5.ŞB. 17/41, 24 Zilkade 1333/3 Ekim 1915. 
BOA, Fon Kodu: DH.MKT. 290/4. 25 Eylül 1894.

BOA, Fon Kodu: DH.UMVM,73/14-19, 3 Cemazeyilevvel 1338/24 Ocak 1920.

BOA, Fon Kodu: ŞD. Dosya No: 1782 B, Gömlek No: 8, Tarihi: 1288 B 08/23 Eylül 1871.

BOA, Fon Kodu: Y.PRK.AZJ 41/62, 2 Şaban 1308/13 Mart 1891.

BOA, Fon Kodu: Y.PRK.ZB,17/28, 9 Ramazan 1313/23 Şubat 1896.

BOA, Tapu Tahrir Defteri, Defter No 52: 698.

BOA, Tapu Tahrir Defteri, Defter No 53:4; 387:718.

BOA. Fon Kodu: DH.MUİ. Dosya No: 95, Gömlek No: 49, Tarihi: 1328 Ca 211910/1911.

Bostan, M. H. (2012). Arşiv Belgelerine Göre Karadeniz'de Nüfus Hareketleri ve Nüfusun Etnik Yapısı, Nöbetçi Yayınevi, İstanbul.

Bostan, M. H. (2013). Giresun Çevresi Çepnilerinin Dini Anlayışı Üzerine Bir Değerlendirme, Geçmişten Günümüze Giresun'da Dinî ve Kültürel Hayat Sempozyumu -I (25-27 Ekim 2013), Giresun İl Özel İdaresi Yayını s. 42-58.

Bostan, M. H. (2002). XV-XVI. Asırlarda Trabzon Sancağında Sosyal ve Iktisadi hayat, Türk Tarih Kurumu, Ankara.

Bostanc1, H. (2007). Osmanlı Döneminde Doğu Karadeniz Bölgesinde Kurulan Tekke Ve Zaviyeler, Firat Üniversitesi Sosyal Bilimler Enstitüsü Tarih Anabilim Dalı Yayınlanmamış Yüksek Lisans Tezi, Elazı̆̆g.

Cöhce, S. (1988). Doğu Karadeniz Bölgesinin Türkleşmesinde Kıpçakların Rolü, Birinci Tarih Boyunca Karadeniz Kongresi (Samsun 13-17 Ekim 1986) Bildiriler. Samsun: Ondokuz Mayıs Üniversitesi Eğitim Fak..

Çulpan, C. (2002). Türk Taş Köprüleri. Ortaçağ’dan Osmanlı Dönemi Sonuna Kadar, Ankara: Türk Tarih Kurumu Yay.

Demir, N. (2005). Orta ve Doğu Karadeniz Bölgesinin Tarihi Alt Yapısl, Ankara: Genel Kurmay Basımevi.

Demirci, Süleyman. (2012). XVII. Yüzyılda Trabzon Eyâletinin İdarî Taksimatı ve Vergilendirilebilir Nüfus: Giresun, Keşap, Kürtün Ve Yavabolu Nam-I Diğer (Görele) Kazâları Örneği. Süleyman Demirel Üniversitesi Sosyal Bilimler Enstitüsü Dergisi (15), 15-29.

Demircioğlu, S. (2008). Tarihin Ayak izleri. Osmanlı Belgelerinde Trabzon, İstanbul: Trabzon Belediyesi Kültür Yayınları. 
Dilaver, G, (2013), Trabzon Illinde Bulunan Araklı Dağbaşı Yeşilyurt Yolundaki Tarihi Hafizlar Köprüsüne Ait ait rölöve, restitüsyon ve restorasyon projesi, Trabzon: Güner Tasarım. Karayolları Genel Müdürlügü 10. Bölge Müdürlüğü. (Trabzon Kültür Varlıklarını Koruma Bölge Kurulu Arşivi) .

Emek, S. S. (2014). Gümüşhane,Kürtün Sarıbaba Köyü Köprüsü Rölöve, Restitüsyon, Restorasyon Projeleri ve Sanat Tarihi Raporu. Trabzon: Karayolları Genel Müdürlügü 10. Bölge Müdürlüğü. (Trabzon Kültür Varlıklarını Koruma Bölge Kurulu Arşivi)

Ersoy, E. (2008). Türklerde Bir İskân Siyâseti Olarak Derbend Teşkilâtı, Doğu Anadolu Bölgesi Araştırmaları, Fırat Üniversitesi Doğu Anadolu Bölgesi Araştırmaları Merkezi, Cilt: 6, Sayı: 2, Şubat, s.,47-53.

Esin, E (1972). Muyanlık, Uygur Buyan Yapısından (Vihara) Hakanlı Muyanlığına (Ribat) ve Selçuklu Han ile Medresesine Gelişme, Malazgirt Armağanı Türk Tarih Kurumu Yayını, Ankara, s.,75-102.

Eskikurt, A. (2014). Ortaçağ Anadolu Ticaret Yolları, Muğla Sitkı Koçman Üniversitesi Sosyal Bilimler Enstitüsü Dergisi, Sayı 33, Güz, s.,1540.

Fatsa, M. (2014). XV ve XVI. Yüzyıllarda Doğu Karadeniz'de Yol Hizmeti Veren Zâviyeler ve Derbendler Vakıflar Dergisi, Haziran, Sayı. 41, Ankara, s.,37-66.

Fatsa, M. (2015). Trabzon Yöresinin İslamlaşma Süreci Ve Zâviyeler, Karadeniz Incelemeleri Dergisi, (18), s.,61-74.

Gökbilgin, M. Tayyib. (1962). "XVI. Yüzyıl Başlarında Trabzon Livası ve Doğu Karadeniz Bölgesi”, TTK Belleten, XXX/102 s., 293-337.

Görkaş, İ. (2000). İslam Felsefesi Açısından Horasan Erenler, Türk Kültürü ve Hacı Bektaş Veli Dergisi, Sayı 15, Ankara, s,191-211.

Gülçiçek, A. D. (2000). Anadolu ve Balkanlar'daki Alevi Bektaşi Dergâhları (Tekke, Zaviye ve Türbeler). Türk Kültürü ve Hacı Bektaş Veli Dergisi (16).

Gündoğdu, H. (2001). Kuzeydoğu Anadolu Yol Güzergâhı ve Karakulak Menzili Atatürk Üniversitesi Güzel Sanatlar Enstitüsü Dergisi, 7, 65-69.

Halaçoğlu, Y. (1995). Klâsik Dönemde Osmanlılarda Haberleşme ve Yol Sistemi, Çağını Yakalayan Osmanlı, Osmanlı Devletiınde Modern Haberleşme ve Ulaştırma Teknikleri, İstanbul, s.,14 (13-21).

Halaçoğlu, Y. (2003). XIV-XVII. Yüzyıllarda Osmanlılarda Devlet Teşkilatı ve Sosyal Yapı. Ankara: Türk Tarih Kurumu Yayınları. 
Halaçoğlu, Y. (1994). Derbend. TDV İslâm Ansiklopedisi (C. 9), 162-164.

Hürriyet. (2019, Temmuz 10). Rize'de 300 Yıllık Kemer Köprü Çöktü: http:// www.hurriyet.com.tr/galeri-rizede-300-yillik-kemer-koprucoktu-41269396/2

İlter, F. (1978). Osmanlılara Kadar Anadolu Köprüleri. Ankara: Karayolları Genel Müdürlüğ̈̈ Yayınları.

Kılıç, O, (1999), XVIII. Yüzyılın İlk Yarısında Trabzon Eyâleti’nin İdari Taksimatı ve Tevcihat1, Trabzon Tarihi Sempozyumu Bildiriler - 6-8 Kasım 1998, Yay. Haz. Kemal Çiçek- Kenan İnan ve diğerleri, Trabzon Belediyesi Kültür Yayınları:75, (Trabzon 1999), s. 179-192.

Kırzıoğlu, M. F. (1992). Yukarı Kur ve Çoruk Boylarında Kıpçaklar. Türk Tarih Kurumu Yayını, Ankara.

Mehmet Rüştü-Mehmet Eşref-Mehmet Nasrullah, (H.1325/M.1909). Vilayet-i Trabzon, Kitaphane-yi Tefeyyuz, Şirket-i Murettibiye Matbaas1, İstanbul 1325. Ölçek1:1.500.000]

Miroğlu, İ. (1997). Osmanlı Yol Sistemine Dair, Prof. Dr. Münir Aktepe'ye Armağan, Tarih Enstitüsü Dergisi (15), 245-250.

Ocak, A. Y. (1978). Zaviyeler, Vakıflar Dergisi (XII).

Orhonlu, C. (1984). Osmanlı Imparatoluğu’nda Şehircilik ve Ulaşım Üzerine Araştırmalar, (der. Salih Özbaran), İzmir.

Orhonlu, C. (1990). Osmanlı Devleti’nde Derbend Teşkilatı, İstanbul: Eren Yayınc1lik.

Özdemir, R. (1994). Osmanlı Devleti'nin Tarikat, Tekye ve Zaviyelere Karşı Siyaseti, OTAM (Ankara Üniversitesi Osmanlı Tarihi Araştırma ve Uygulama Merkezi Dergisi (5).

Özmenli, M. (2016). Ortaçağ’da Doğu Karadeniz'de Oğuz ve Kıpçak Yerleşimi, Atatürk Üniversitesi Sosyal Bilimler Enstitüsü Dergisi. Nisan, 20 (2) s., 515-536.

Pakalın, M. Z. (1993). Osmanlı Tarih Deyimleri ve Terimleri Sözlüğü, C.III, Milli Eğitim Bakanlığı Yayınları, İstanbul.

Ribat, Ana Britannica C. 18, s. 388.

Ribat, Türk Ansiklopedisi, Milli Eğitim Bakanlığı Yayınları, C. 27, Ankara 1978, s. 318.

Rumsey, D. (a). Trabizond Vilayeti 1909. David Rumsey Map Collection: 
https://www.davidrumsey.com/luna/servlet/detail/ RUMSEY 8 1 311601 90081061 (Erişim:Ağustos 2019)

Safi, M. (2019). Köprüler Yaptırdım Askoroz Deresine. Kurtuluş Savaşı Sürerken Osmanlı Rize'de Köprü Yaptırlyor, https://www.turkishnews. com/tr/content/2009/11/02/kopruler-yaptirdim-askoroz-deresine/ (Erişim: Ağustos 2019)

Sümer, F. (1972), Oğuzlar (Türkmenler)Tarihleri Boy Teşkilatı Destanları, Ankara: A.Ü. DTCF Yayınları.

Sümer, F. (1992). Çepniler. İstanbul: Türk Dünyası Araştırmaları Vakfı Yayınları.

Şemseddin Sami. (2015). Kamus-ı Türki - Osmanlıca Türkçe Sözlük, (Yayına haz. Adıgüzel, N-Gündoğdu, R- Önal, E.F.), İstanbul: İdeal Kültür Yayıncilık.

Şentürk M. H. (2002). Tanzimat Devrine Kadar Osmanlı Devleti'nin Ulaşım Teşkilâtı ve Yol Sistemine Genel Bir Bakış, Türkler (X), (904-912), Ankara: Yeni Türkiye Yayınları.

Tosun, M. D. (2013). Karahisar'ın Tarihi Köprüleri: https://muratdursuntosun. wordpress.com/2013/02/14/karahisarin-tarihi-kopruleri/ (Erişim:Temmuz 2019)

Tosun, M. D. (2016). Alucra Gürbulak Köyü. Nam-I Diğer Çubuk, Feygas, Hanuk, Şeyh Mehmed. İstanbul: Milsan Basın Sanayii A.Ş., .

Tosun, M. D.(2019), 1880TarihliBelgelerdeŞebinkarahisar Tarihinin Bilinmeyenleri; Karahisar'in Tarihi Köprüleri. https://muratdursuntosun. wordpress.com/2015/12/07/1880-tarihli-belgelerde-sebinkarahisartarihinin-bilinmeyenleri/ (Erișim: Ağustos 2019)

Tuncer, O. C. (2007). Anadolu Kervan Yolları. Vakıflar Genel Müdürlüğü Ankara.

Turan, O. (1984), Selçuklular Zamanında Türkiye Tarihi, Nakışlar Yayınevi, İstanbul.

Turan, O. (2009). Selçuklular Tarihi ve Türk İslâm Medeniyeti, İstanbul: Ötüken Yayınları.

Türkiye Kültür Portali. (2018). Gezilecek Yerler / Ambarlık Köyü Köprüsü. Rize. https://www.kulturportali.gov.tr/turkiye/rize/gezilecekyer/ ambarlik-koyu-koprusu

Yavuz, A. T. (1992). Anadolu Selçuklu Kervansaraylarında Mekân-İşlev İlişkisi İçinde Savunma Ve Barınma, 9. Vakıf Haftası Kitabı, (253-284), Ankara: Vakıflar Genel Müdürlüğü. 
Ege Üniversitesi, Edebiyat Fakültesi Sanat Tarihi Dergisi

ISSN $1300-5707$

Cilt: XXVIII, Sayı: 2 Ekim 2019
Ege University, Faculty of Letters

Journal of Art History

e-ISSN 2636-8064

Volume: XXVIII, Issue: 2 October 2019

\section{İternet Sayfası (Aclk Erisim) | Internet Page (Open Access) \\ DergiPark \\ https://dergipark.org.tr/std}

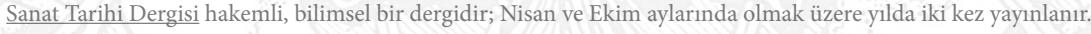

Lournal of Art History is a peer-reviewed, scholarly, periodical journal published biannually, in April and October. 